
ті́TuLo

Desenhar Chã

PRIMEIRA EDIC̣ÃO

2019

EDIC̣ÃO

i2ADS

ORGANIZAC̣ÃO

José Carlos de Paiva

Sílvia Simões

ILUSTRAC̣ÃO CAPA

Sílvia Simões

CONCEÇÃO E DESIGN

Gráficos Associados

IMPRESSÃO

Diário do Minho

TIRAGEM

200 exemplares

ISBN

978-989-54703-3-4

DEPÓSITO LEGAL

468957/20

(c) i2ADS, 2019 


\section{DESENHAR CHÃ}

em Chã das Caldeiras, na Ilha do Fogo, Cabo Verde 


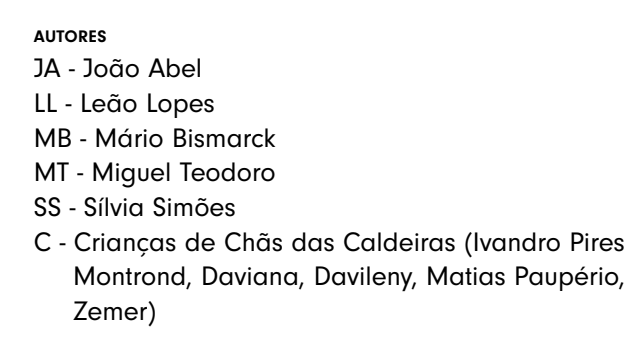




\section{o que nos salva do nada}

Na Ilha do Fogo, em Cabo Verde e nas povoações de Chã das Caldeiras, o Instituto Universitário de Arte, Tecnologia e Cultura (M_EIA), promove com as populações um programa de reassentamento urbano, de superação da calamidade originada pelo vulcão que em 2014, mais uma vez, inundou de lava incandescente as casas e as suas terras. O movimento intercultural IDENTIDADES e o programa de investigação do Colectivo de Acção/Investigação ID_CAI tornou-se ao longo dos anos cúmplices dos desígnios do M_EIA e de suas acções junto de comunidades nas Ilhas de Cabo Verde, e nesse movimento se envolveu no que decorre em Chã das Caldeiras. Desta vez, dois professores e investigadores da FBAUP/ i2ADS (Mário Bismarck e Sílvia Simões), acompanhados de dois estudantes do ID_CAI (Miguel Teodoro e João Abel Mota), para lá se deslocaram em 2018, cúmplices do que acontecia e ansiosos pela proximidade com o que por lá acontecia.

Da sua estada resulta o livro presente, onde se oferecem parte dos desenhos por si realizados, por Leão Lopes (M_EIA) e por crianças da comunidade. E textos redigidos na digestão do vivenciado, que permitem apresentar o outro olhar de cada um sobre o que o desenho procurou entender. Desenhos que perseguem a possibilidade de abandono dos gestos de representação que os habitam, para frequentarem os desafios epistemológicos de entendimento do que nos é estranho e de como o oculto e o indiscritivel nos fazem falta, e colaboram com "o que nos salva do nada”.
"Disseste: A correspondência entre a imagem e a realidade conduz a imaginação à neutralidade. Deixa, portanto, a imagem do objecto mentir ao objecto para que possamos ver o que há além, e à luz dessa visão vermos o que nos salva do nada."

Mahmoud Darwich. 2018. Na Presença da Ausência. Flaneur, tradução de Manuel Alberto Vieira. p. 132

Queria apelar para que este livro fosse usado na dimensão da sua incompletude. Que se tornasse evidente que no relacionamento intercultural o que se passa, as vivências ocorridas, o olhar e os desenhos feitos, apenas pode ser assimilado na fragilidade da sua contingência, na insuficiência de compreensão do que lhes é imanente.

A complexidade que se apresenta na paisagem e nos que dão vida pela sua pertença persistente a este mágico território, esconde-se, oculta-se numa dimensão sem tradução possível para quem lhe é externo. A deslocação para Chã das Caldeiras aproxima, entranha a hospitalidade da população, carece inevitavelmente de a interiorizar.

Aceitar, que chegar a Chã das Caldeiras faz emergir a impotência das palavras e a pequenez de qualquer gesto que tente abranger a dimensão da resiliência oculta na população, que erupção atrás de erupção persiste em habitar aquele lugar sublime e paradoxal e insiste na pertença àquela sua comunidade.

O livro, nessa dimensão discreta, torna-se um objecto de cumplicidade, de apreço. 


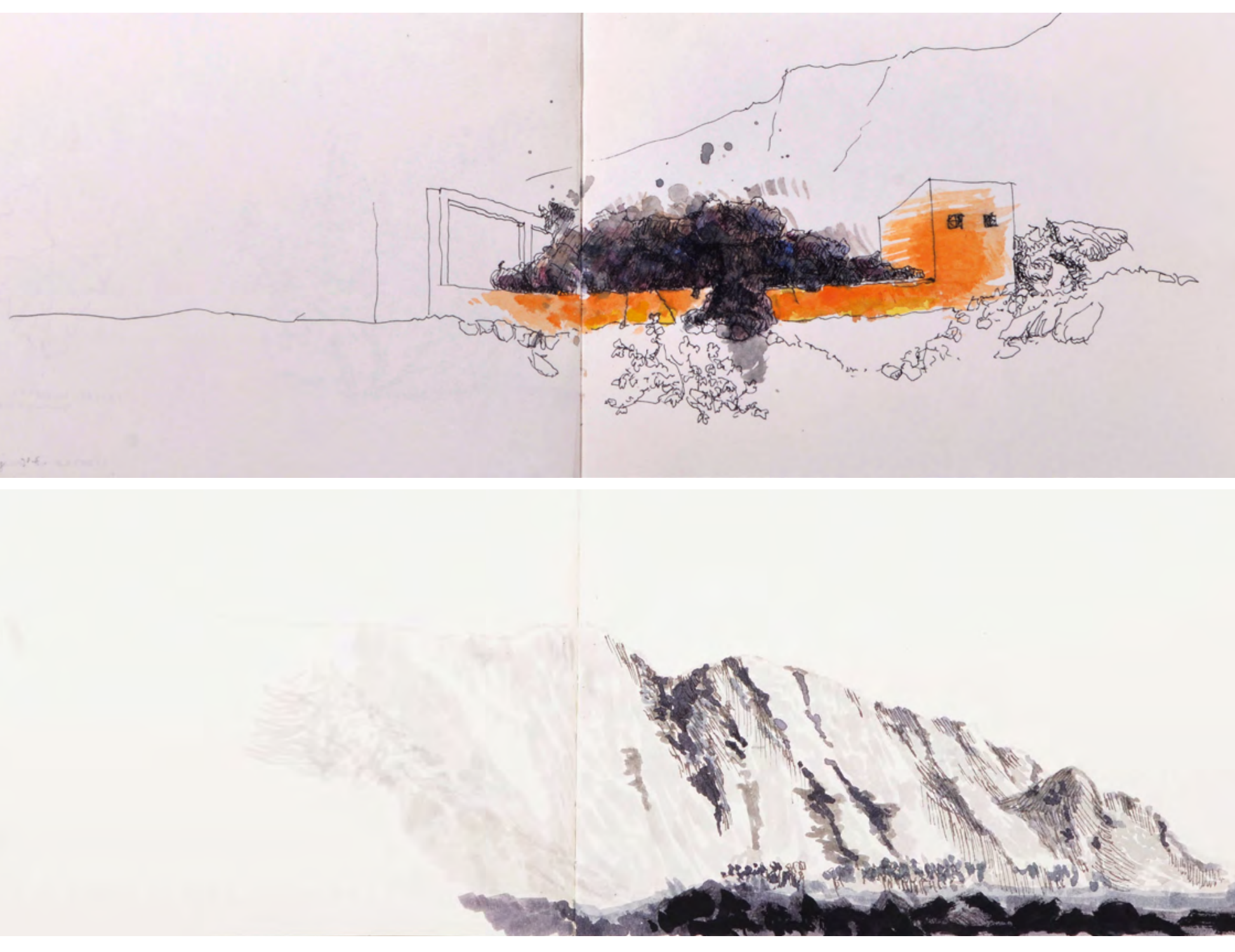












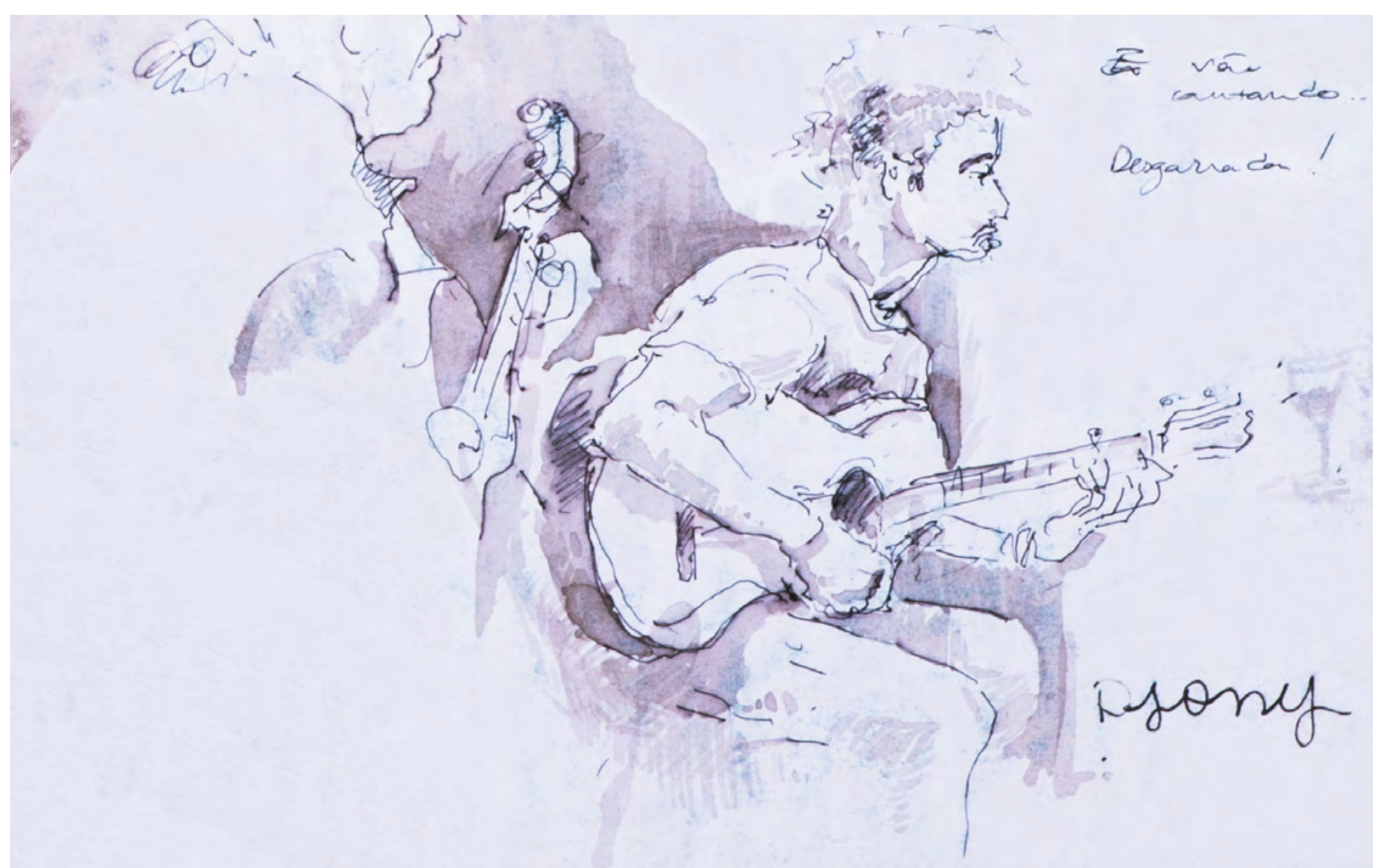





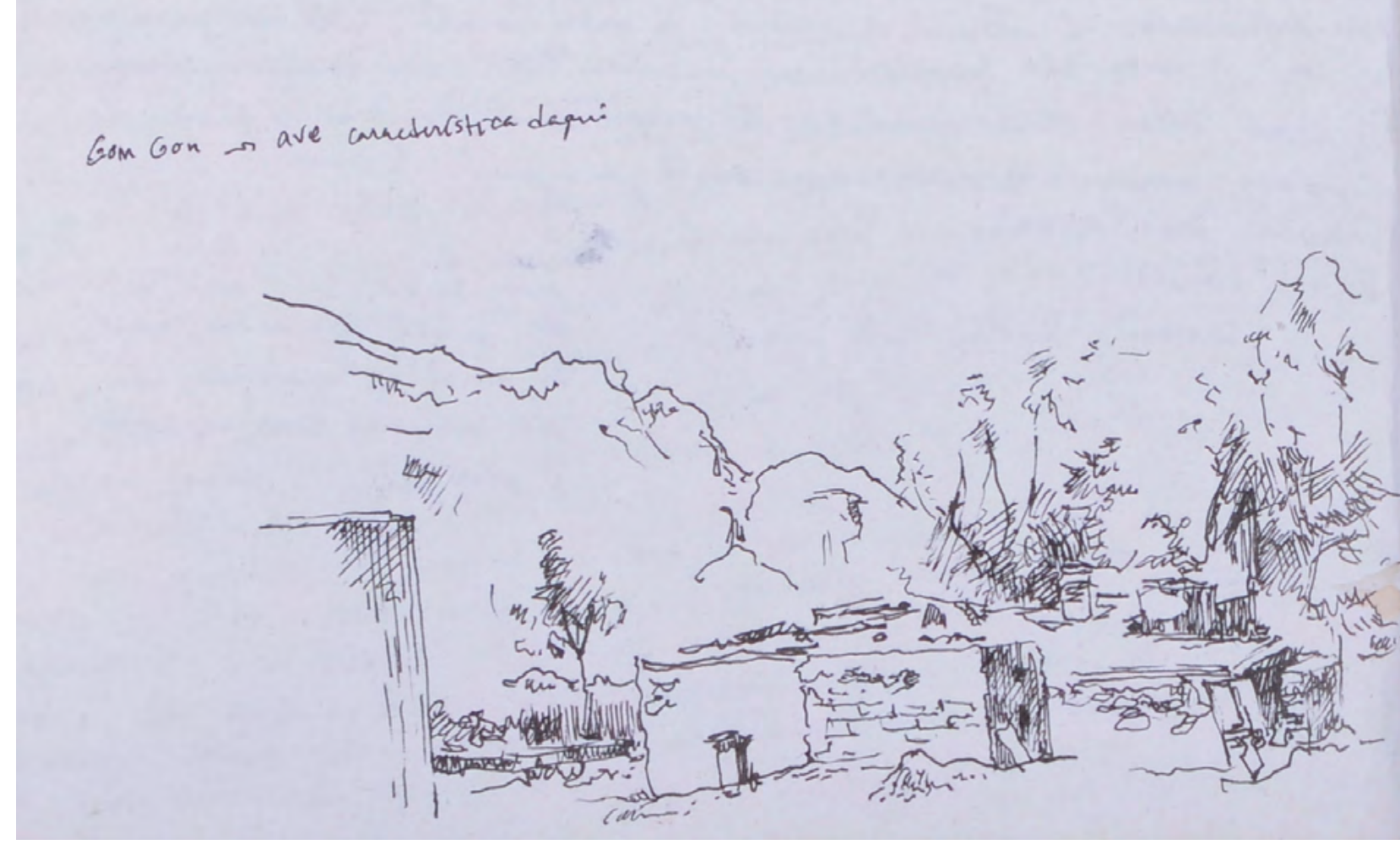





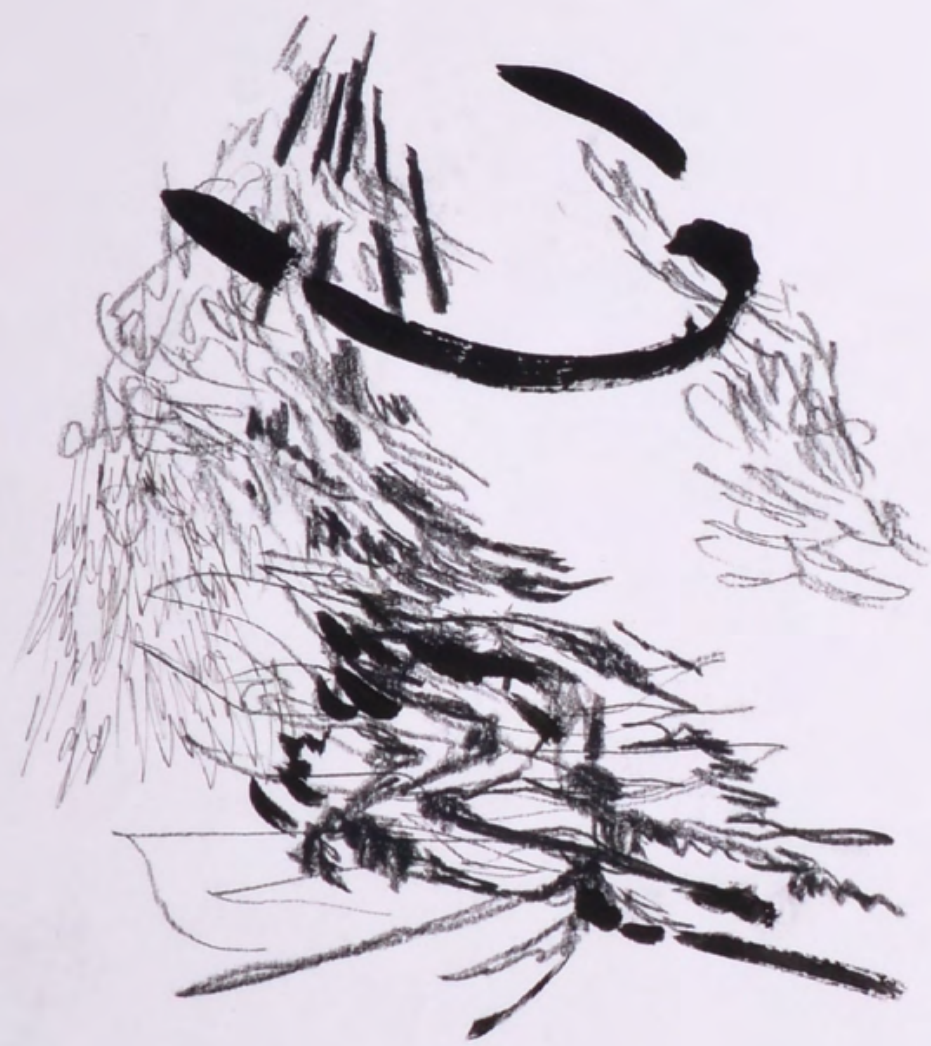




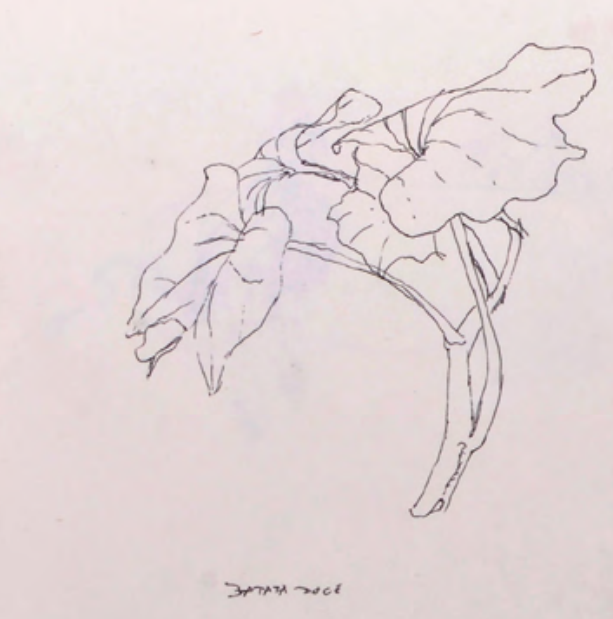




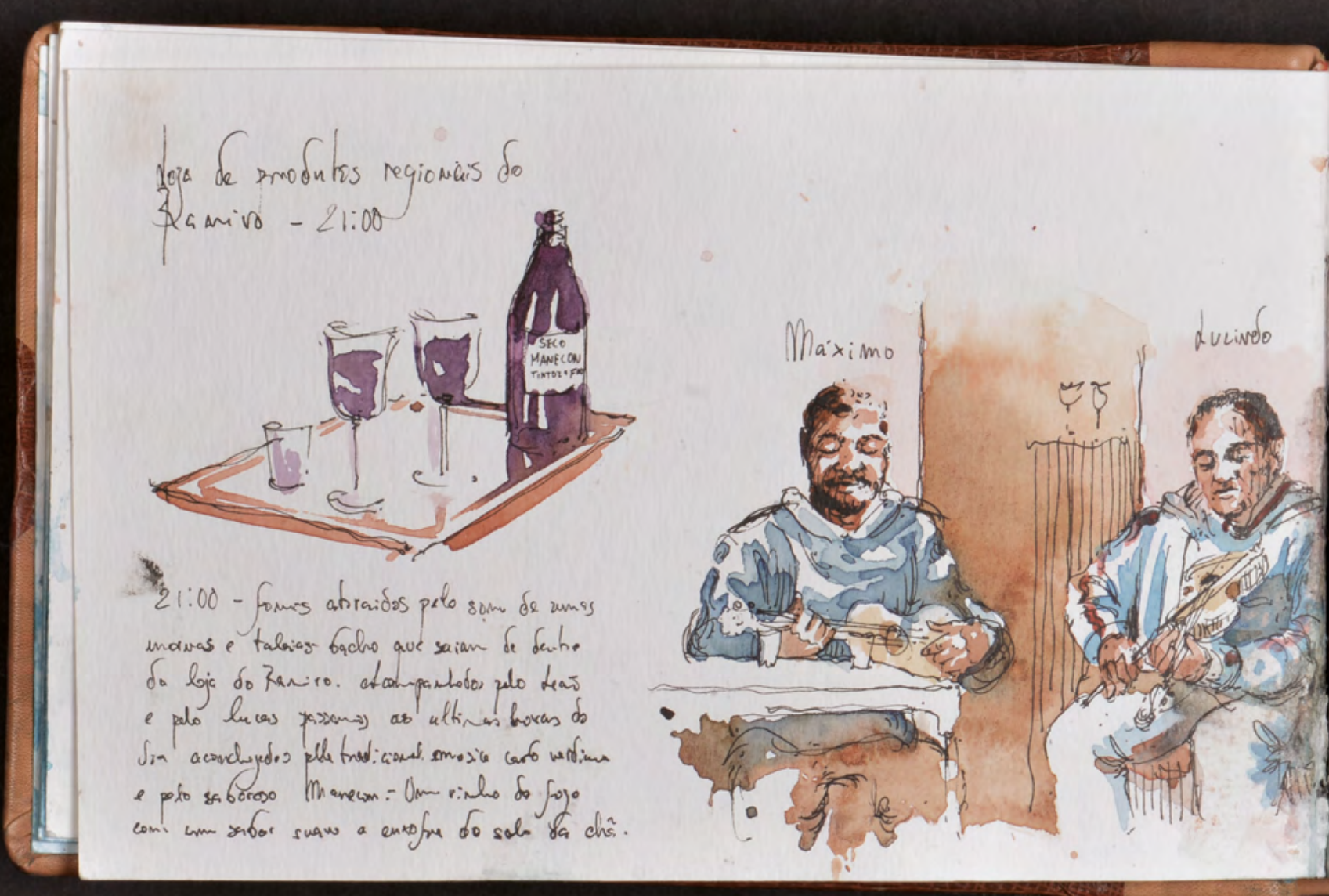




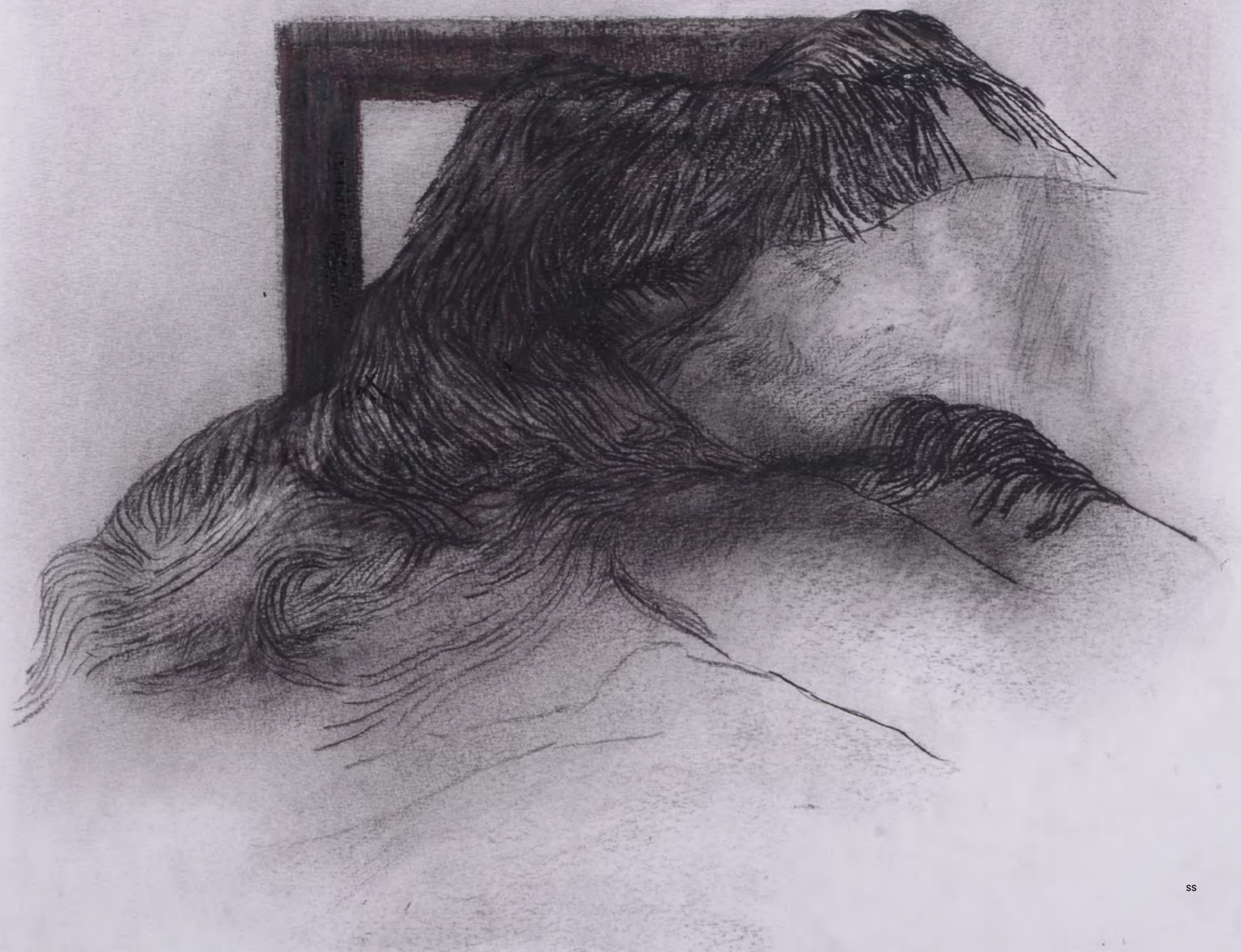




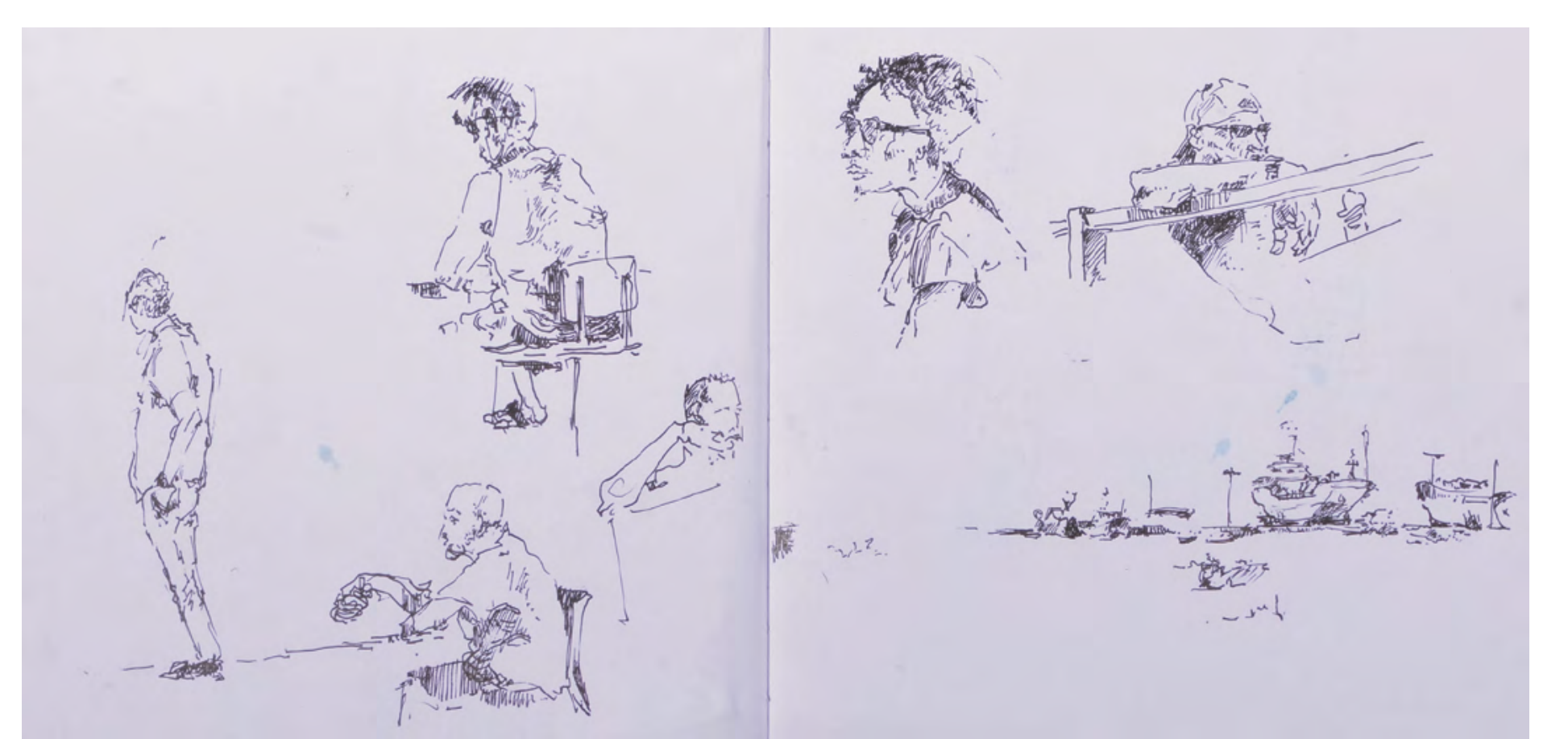





















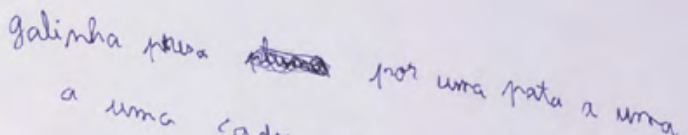

a uma cadeira de ferro

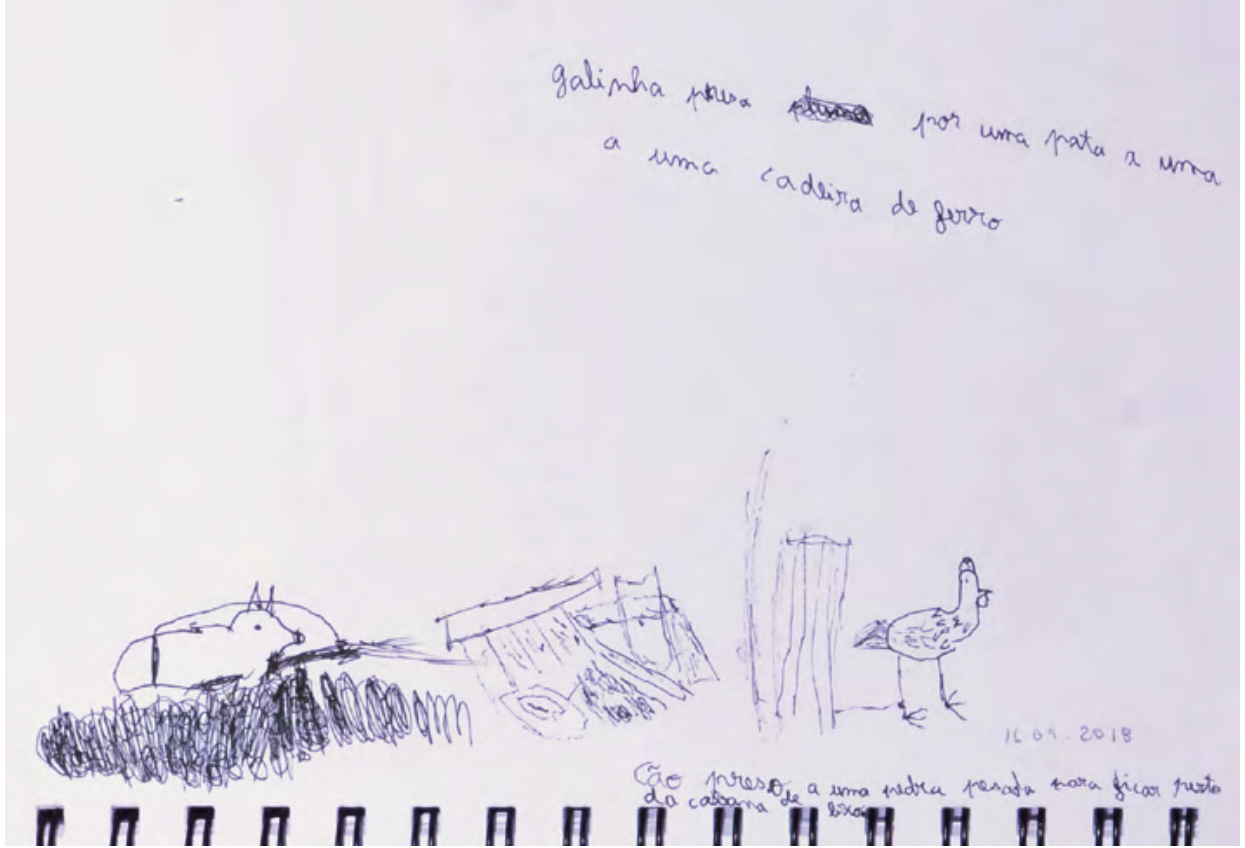

C 


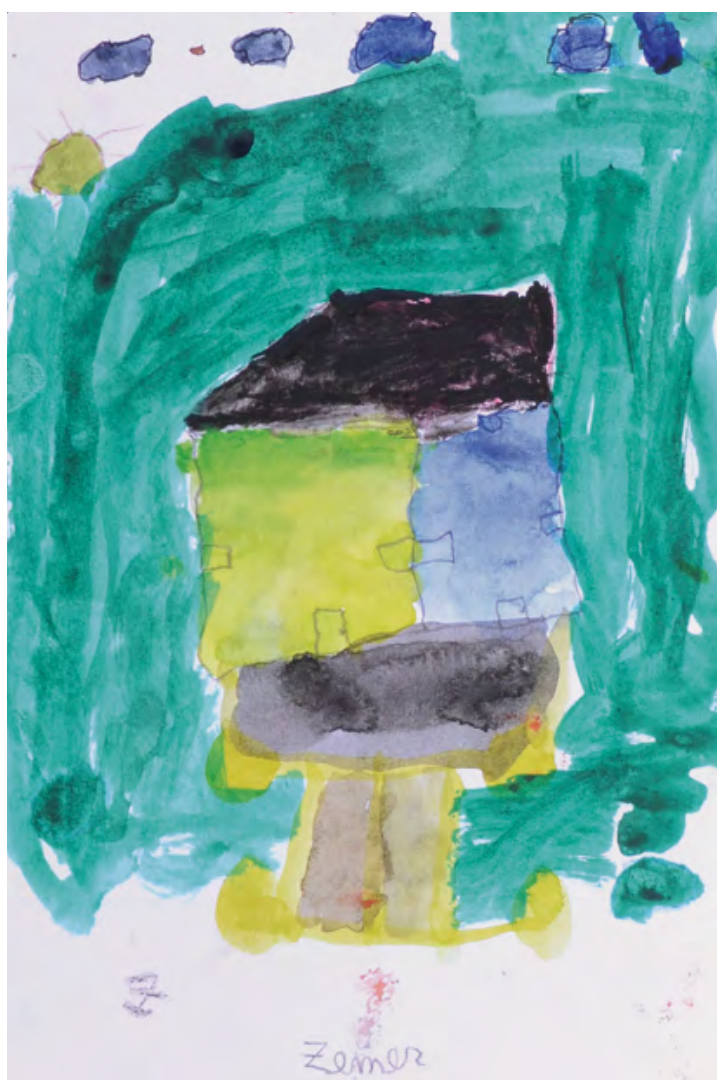




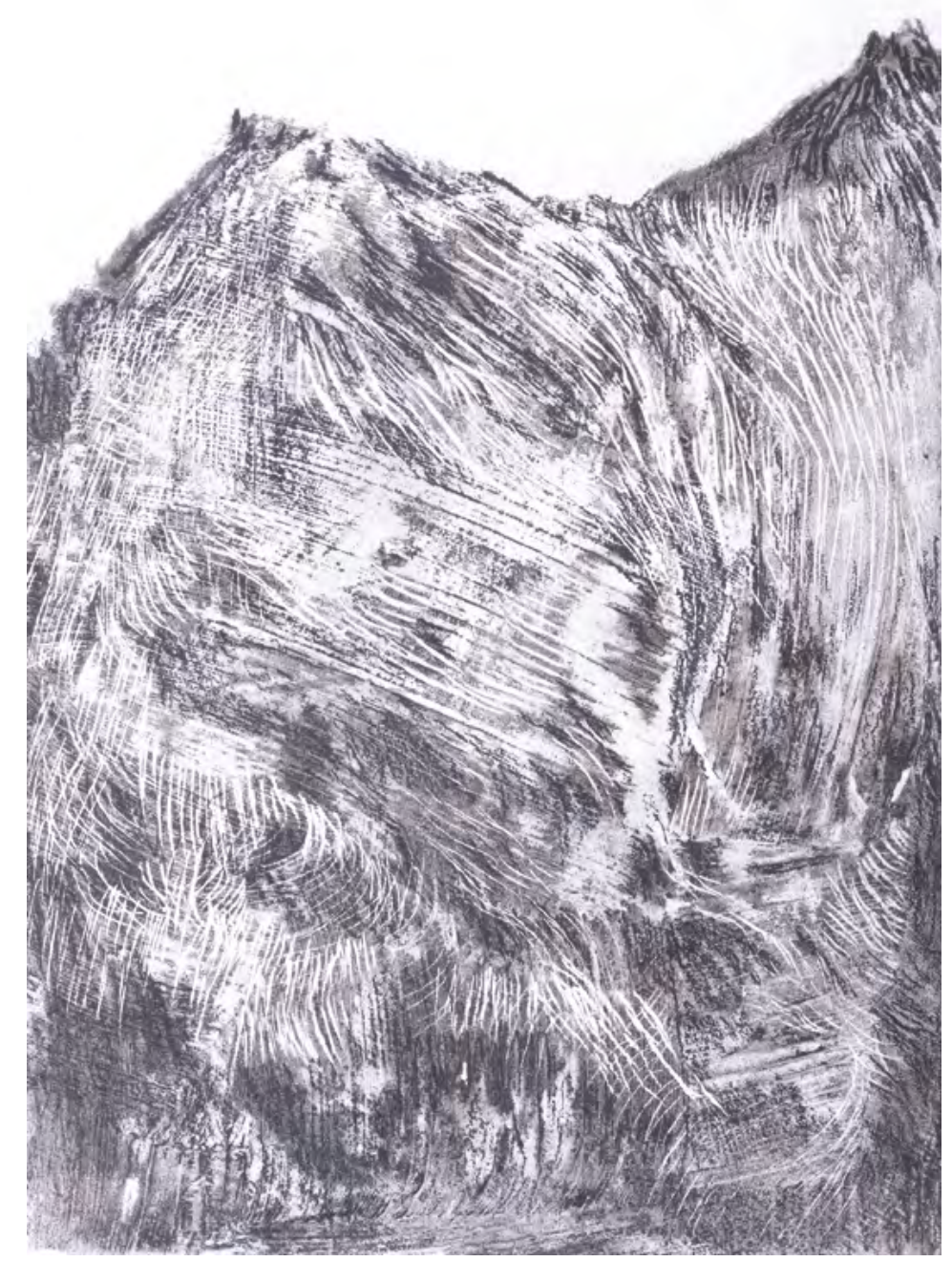






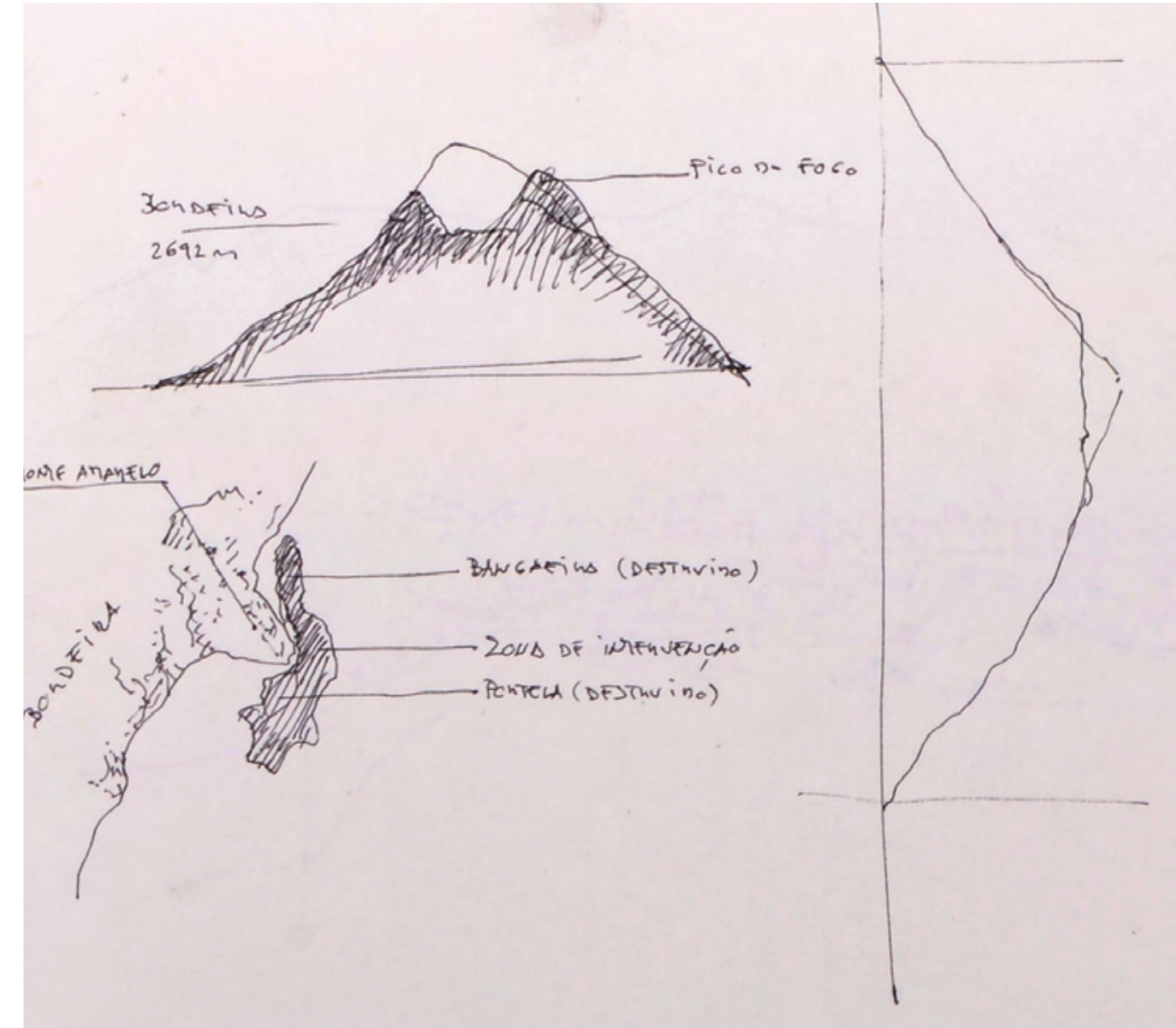




Zemer, miúdo de 6 anos de cabo - verbe (ensisnorme) a jogar ourl ensimou-me

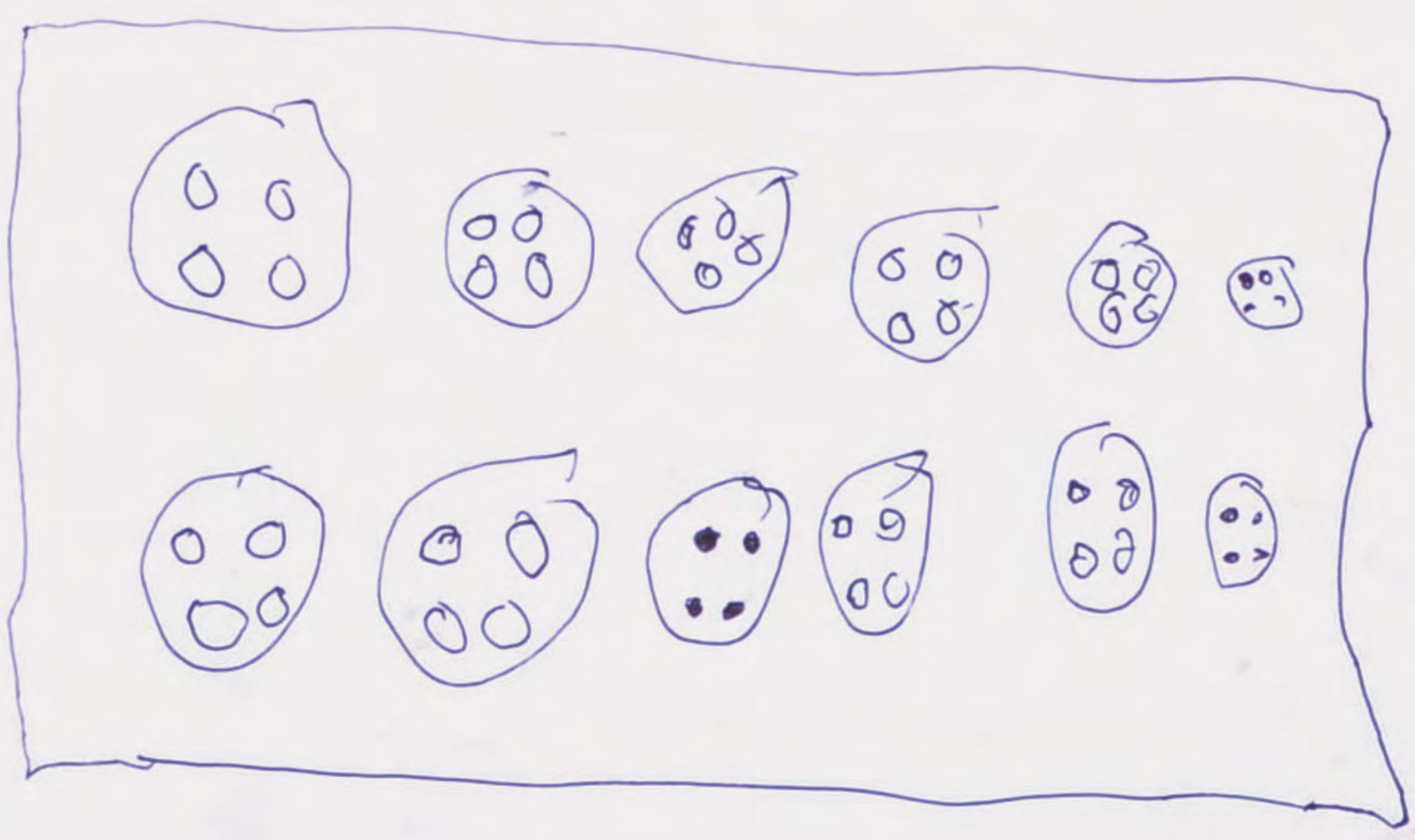

jogo do ouril 







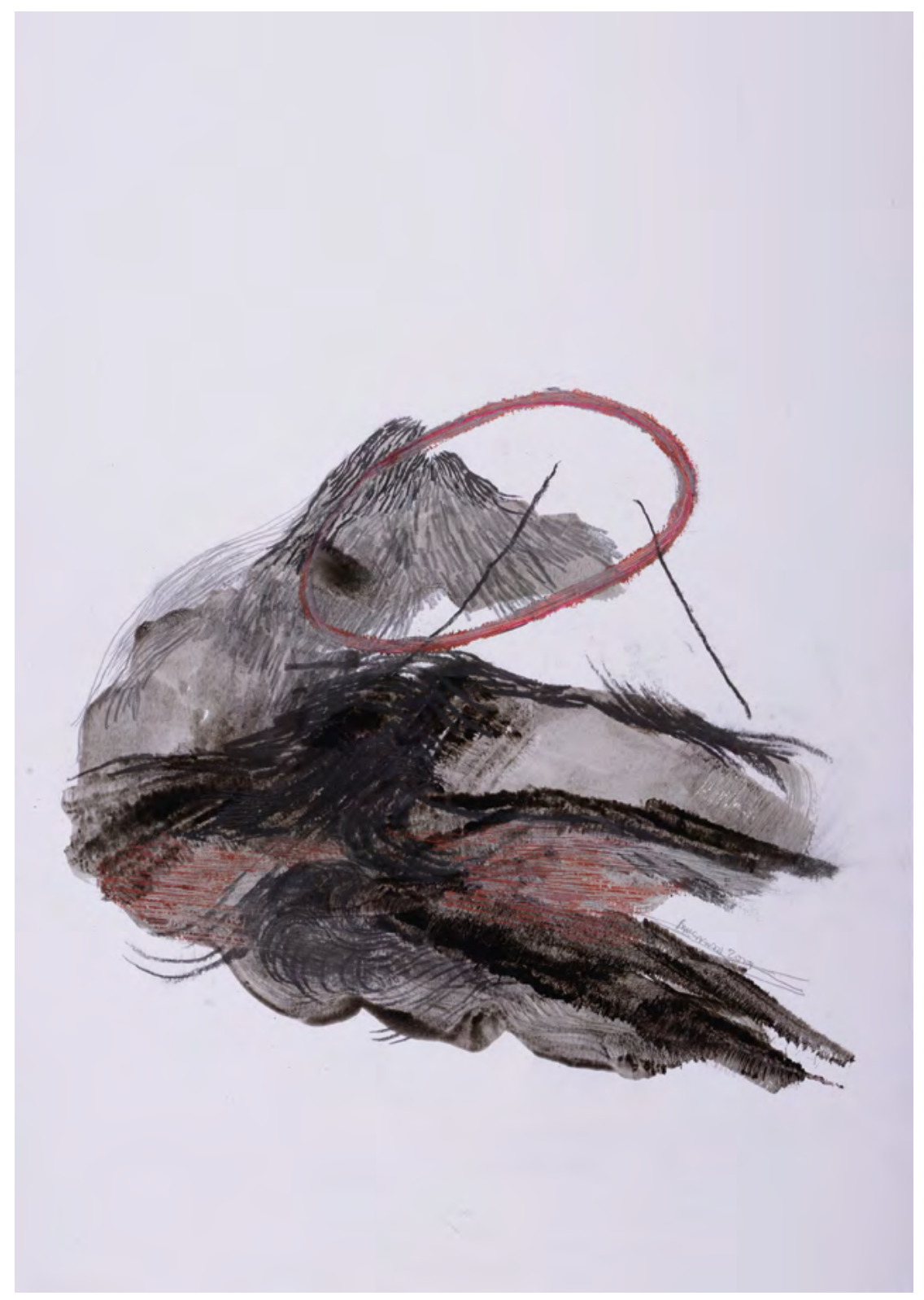




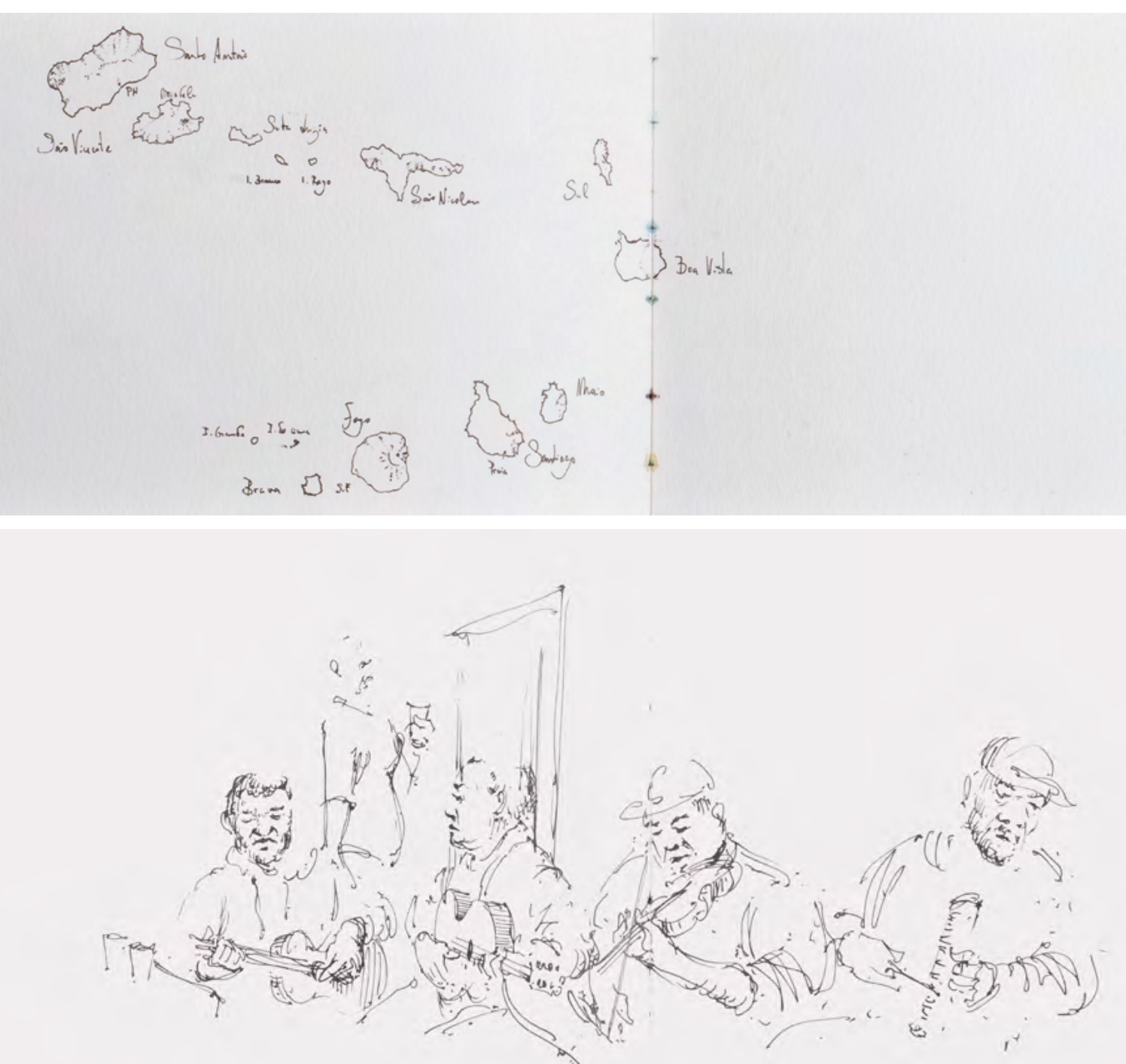




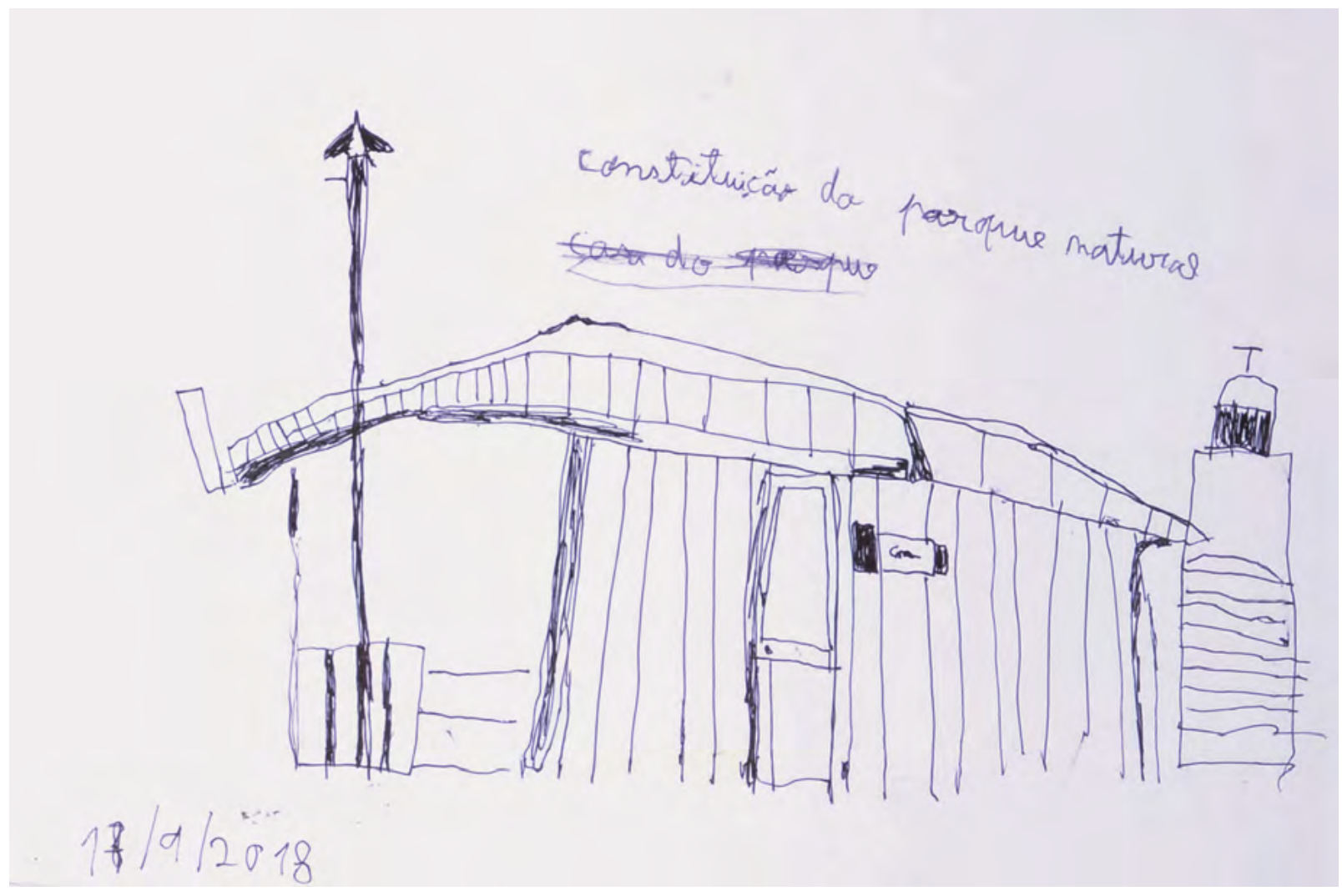

c 




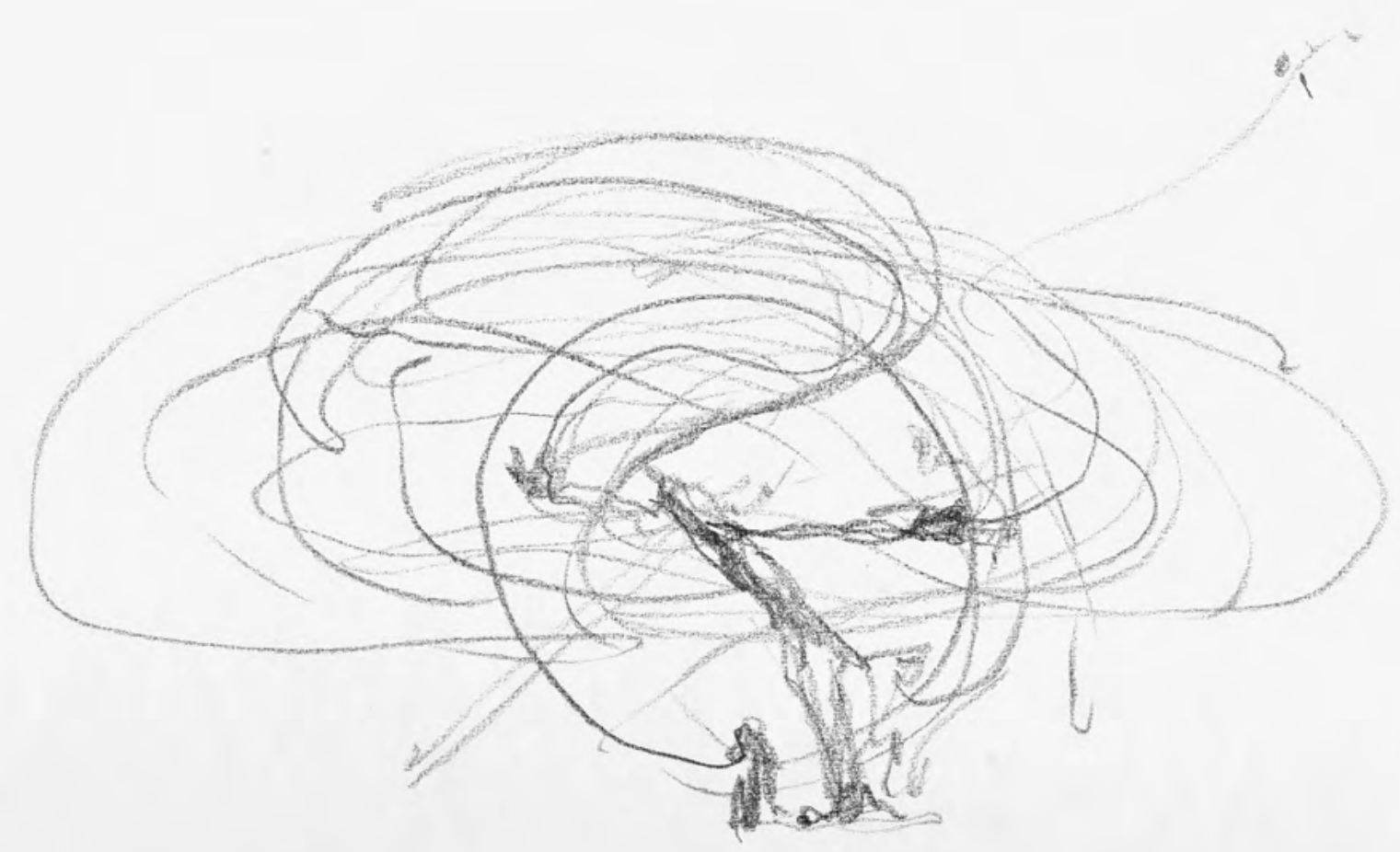

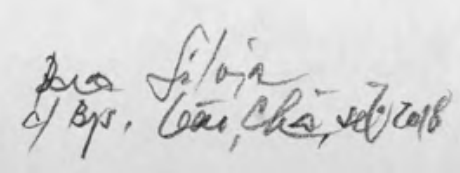




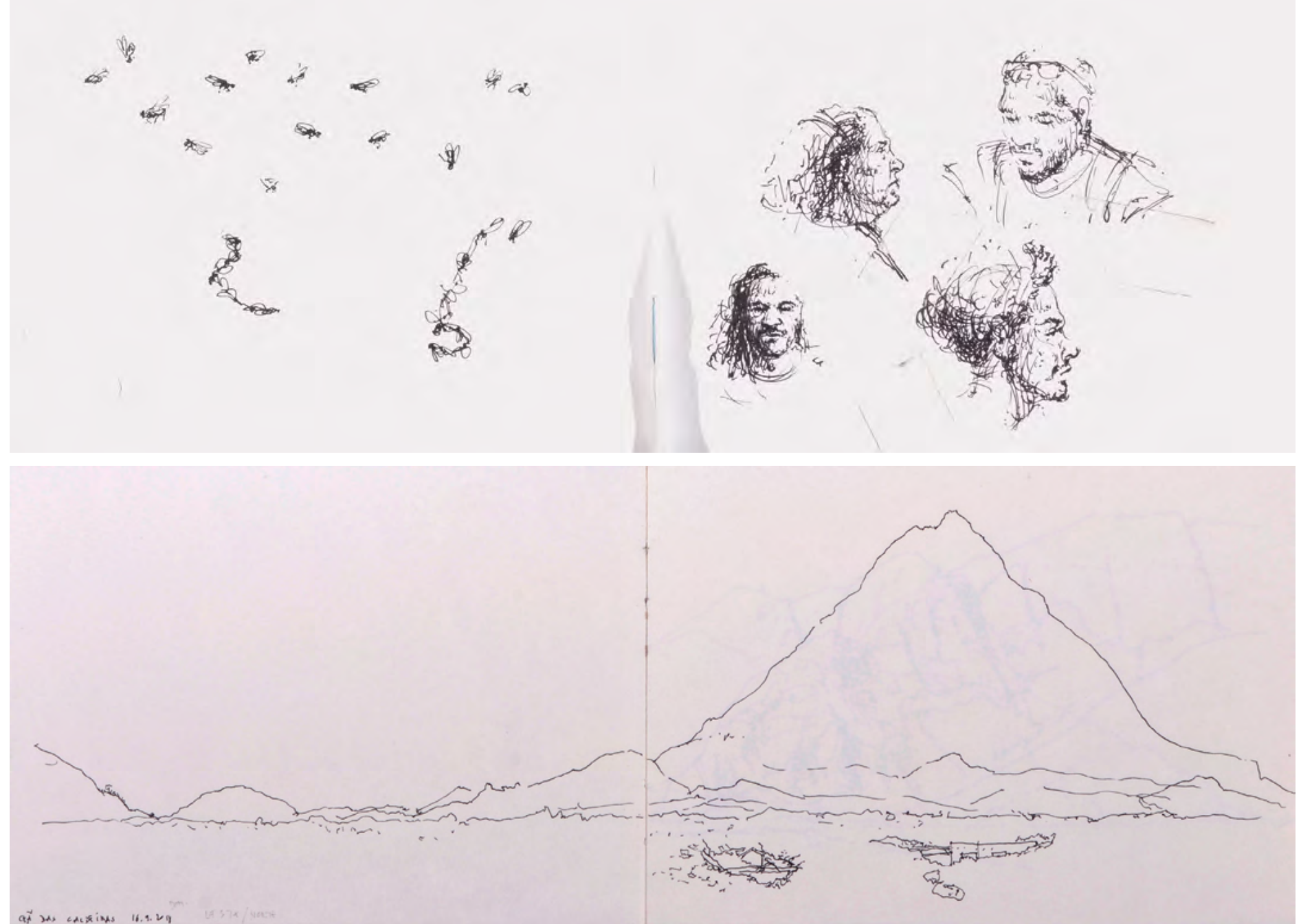



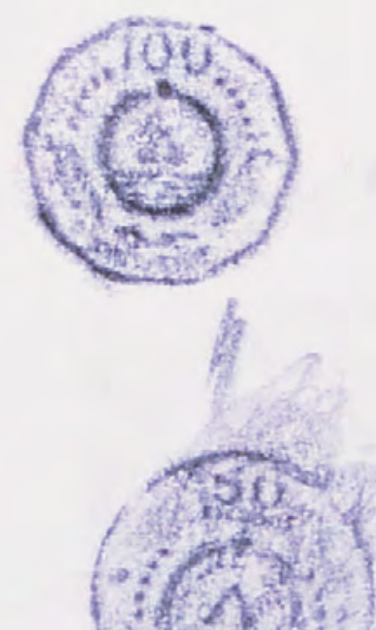

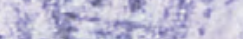

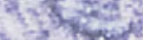

$\lim _{2} x^{2}$
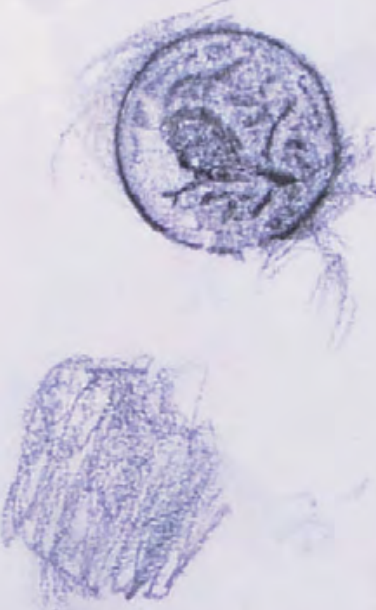
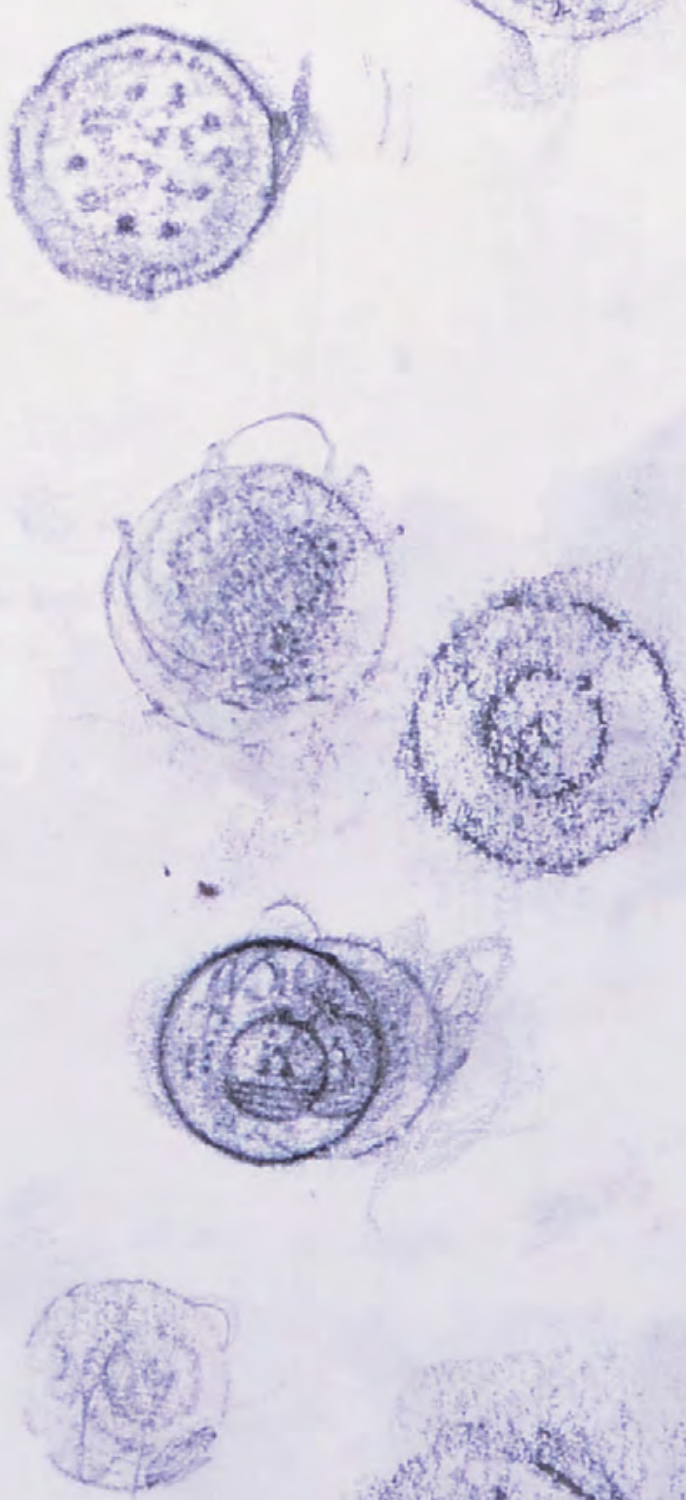


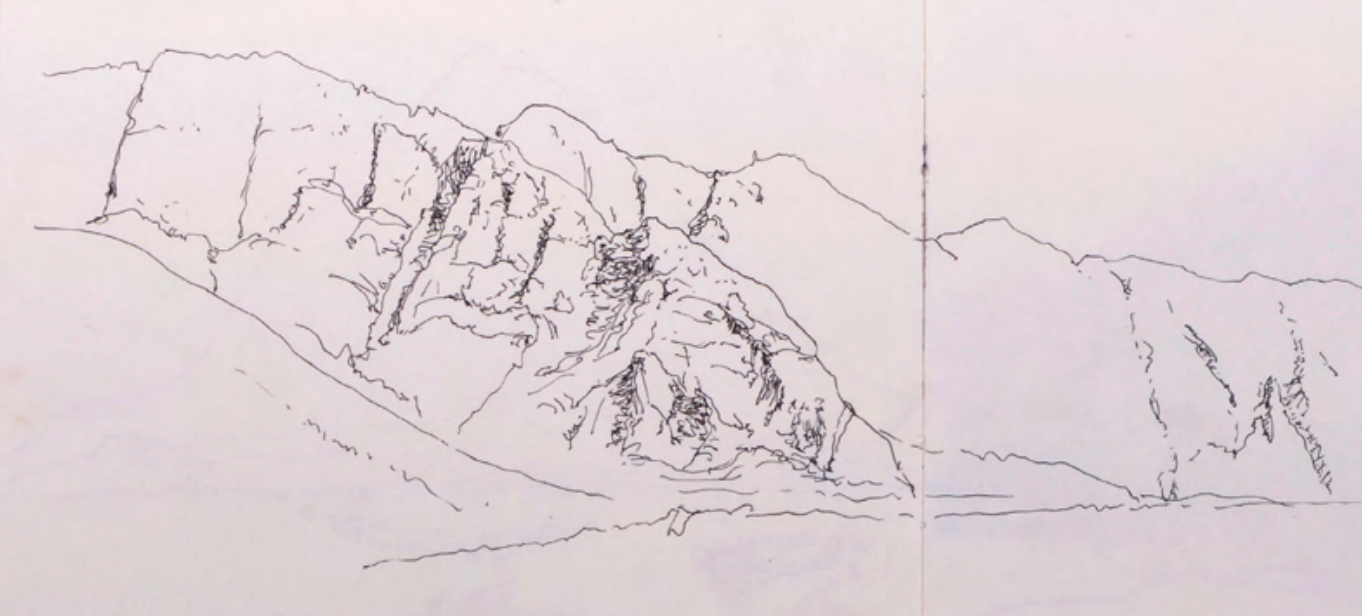




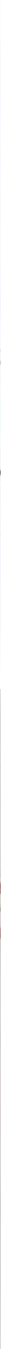


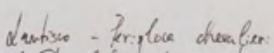

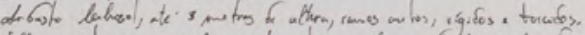

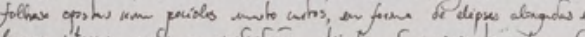

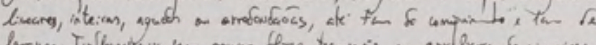

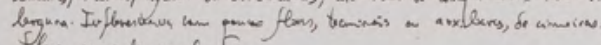

Flone ancule - comensindor.


(5) $3 x$

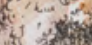

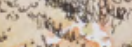

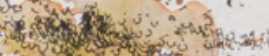

4.

2

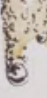

5 ?
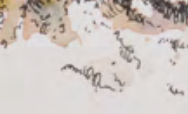


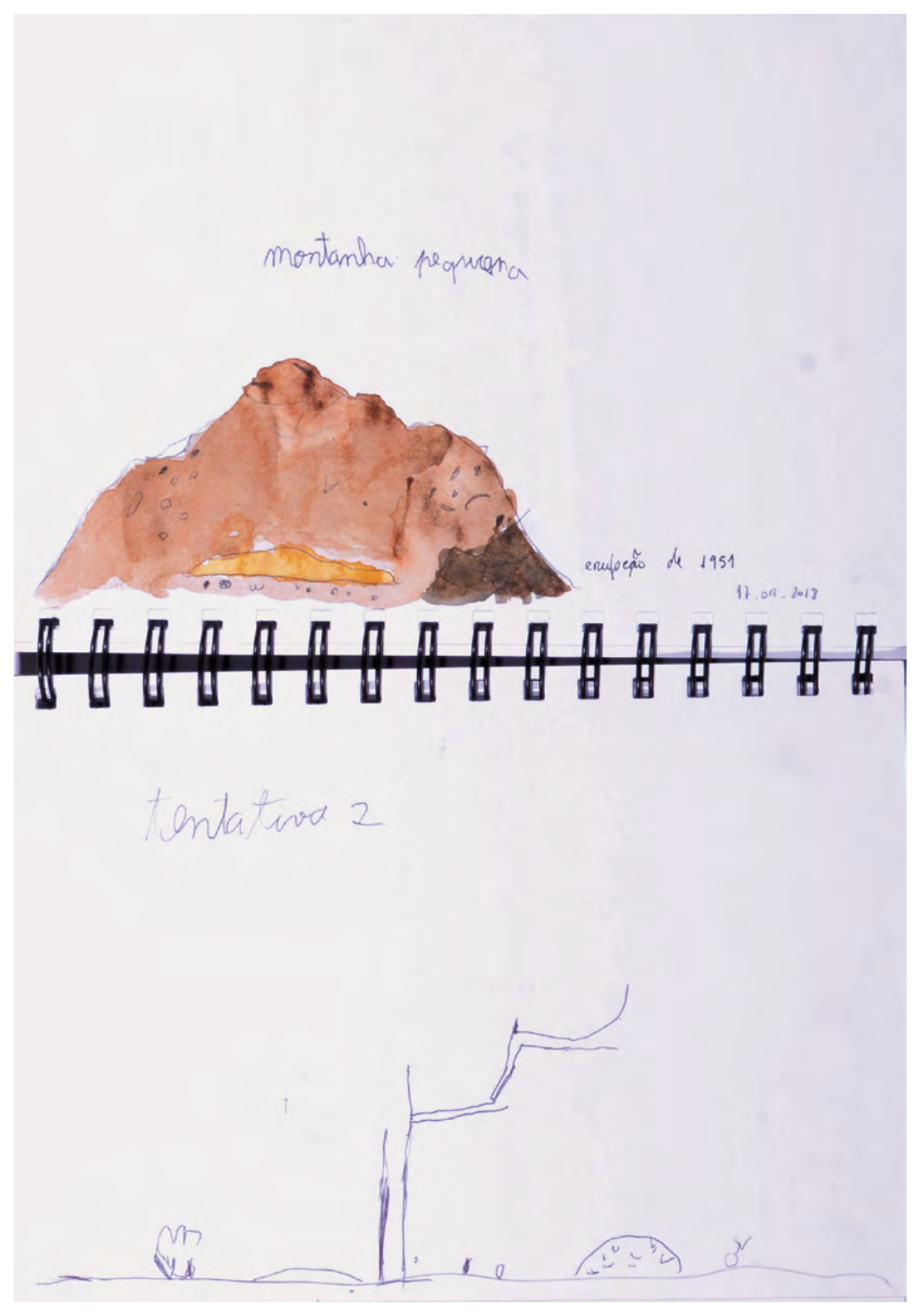




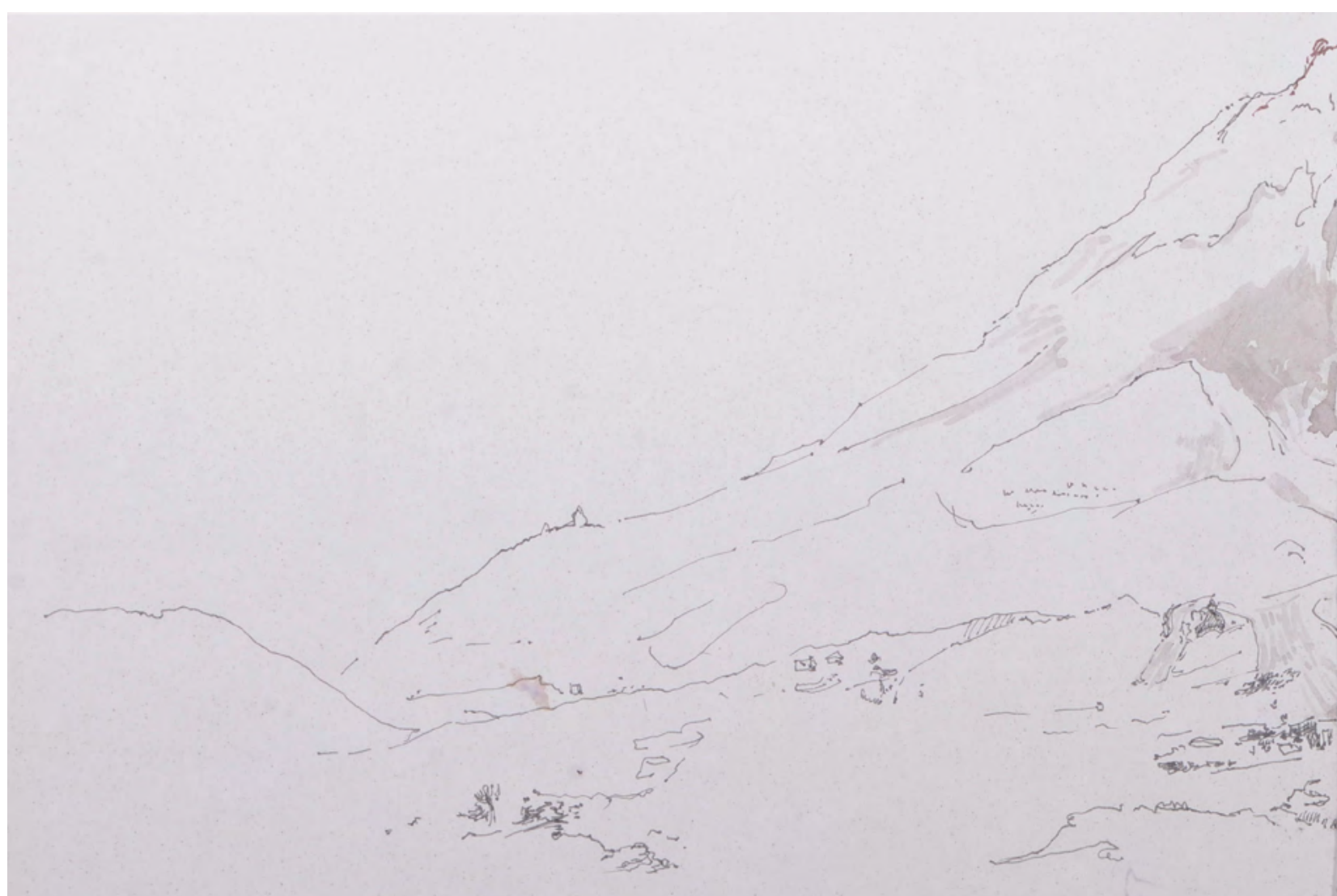





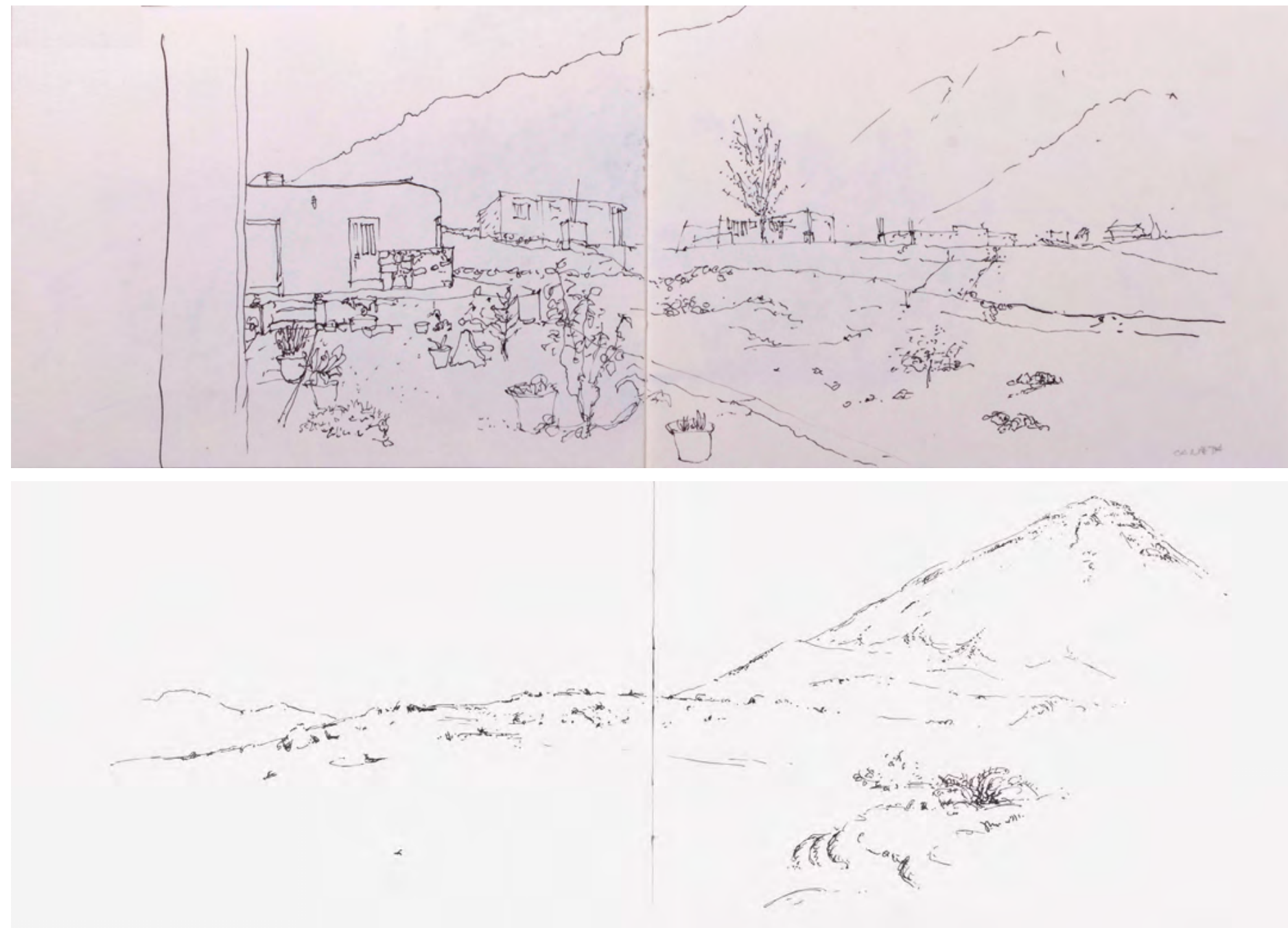




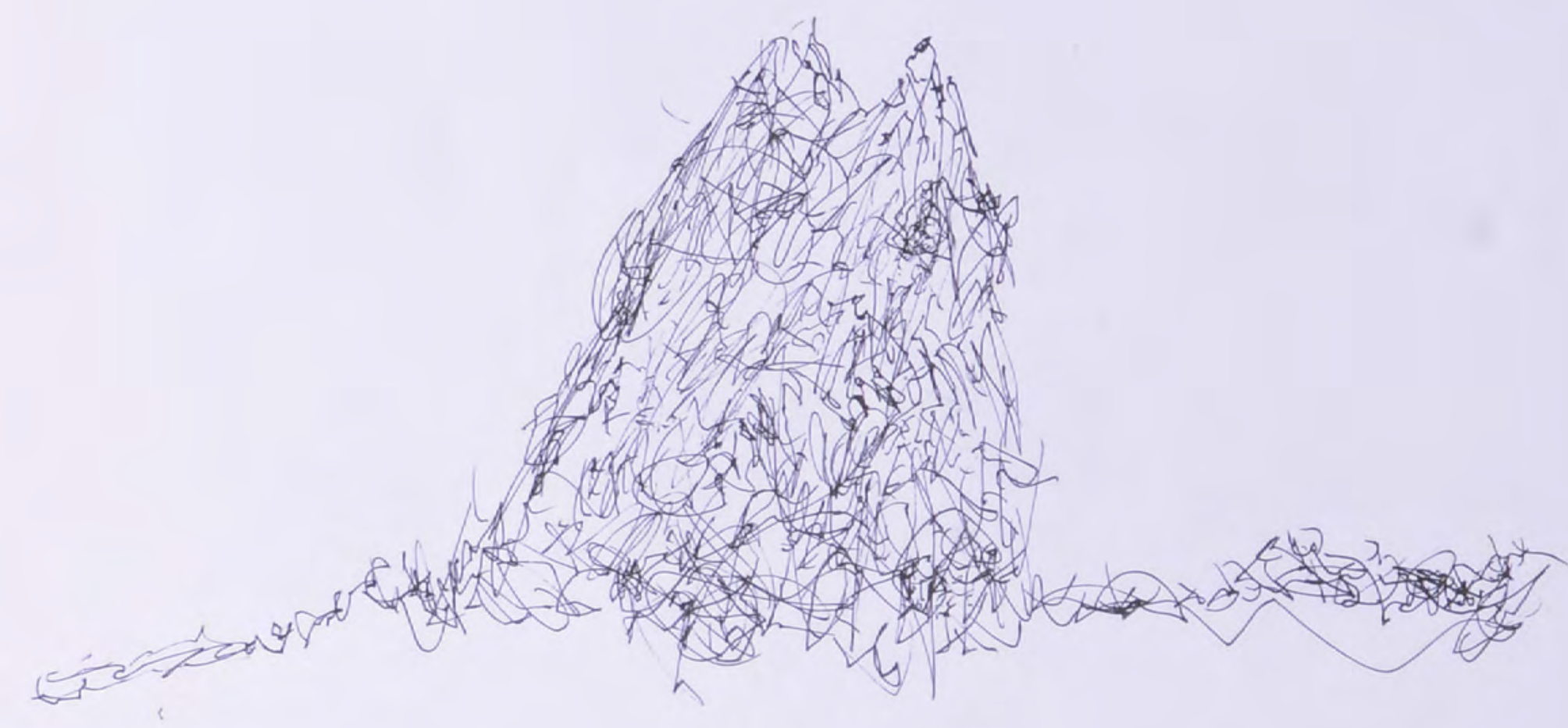




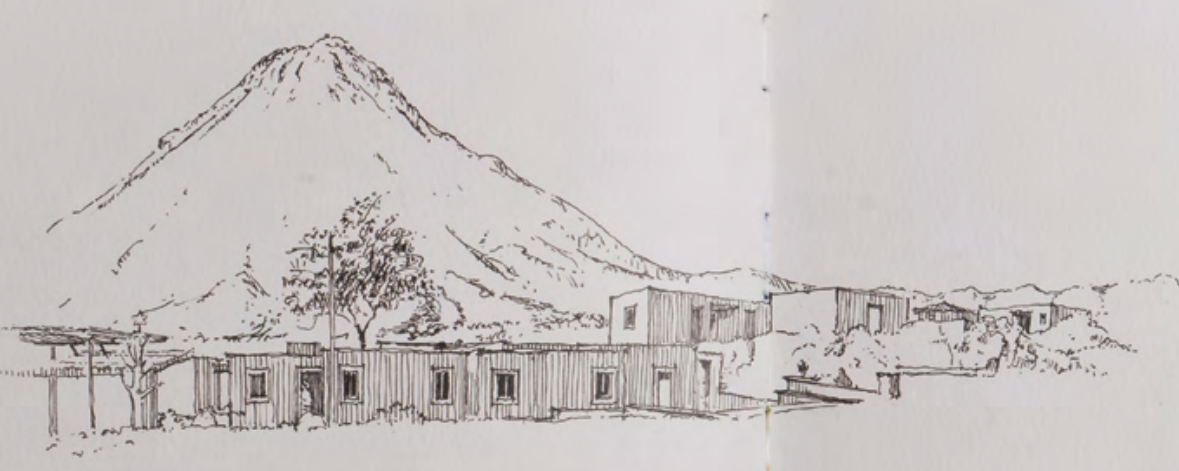



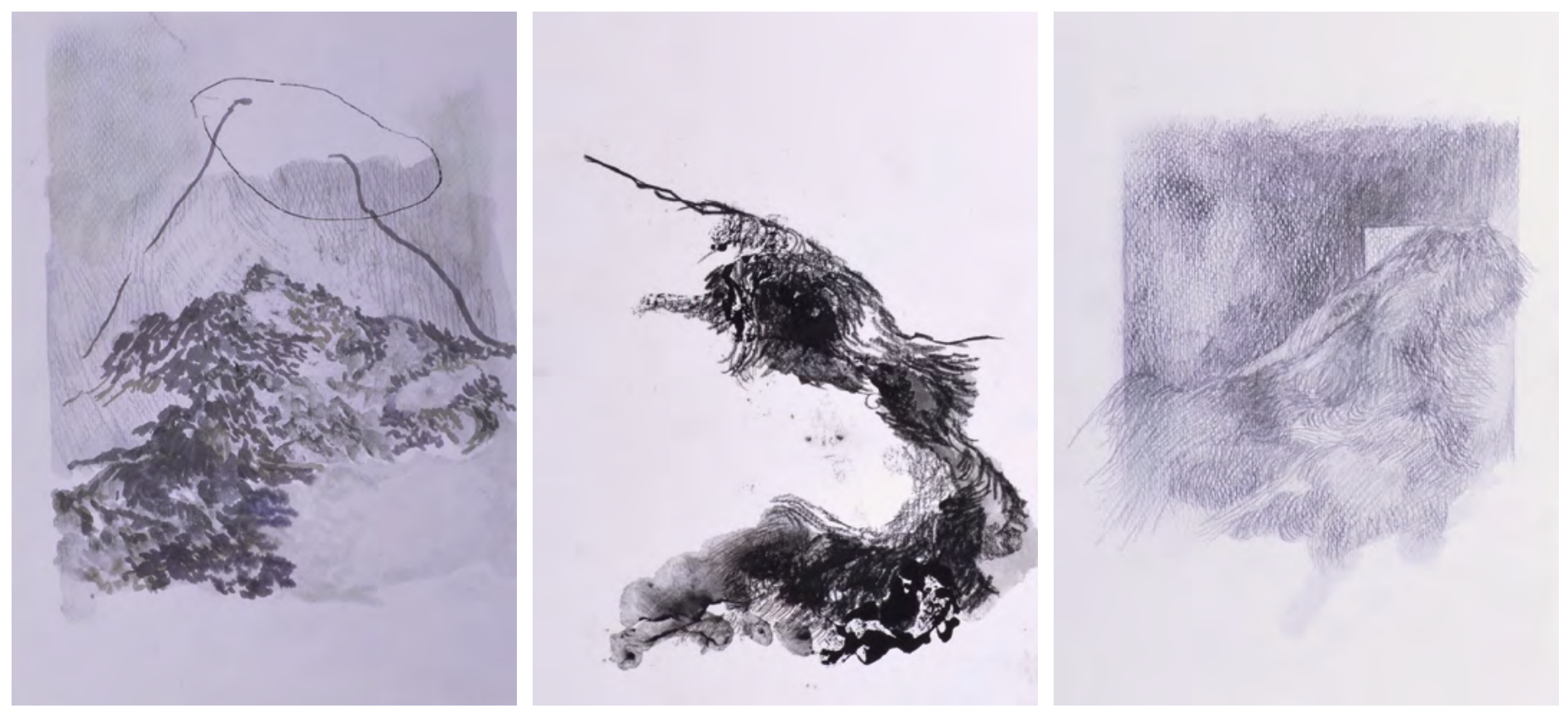


pingue-de- Vaca. Echium vulcanorum

Audus to minito ran froda, ate $1,5 \mathrm{~m}$ he Atira. Cauble coberto pox ma reventimito de plo derso. Folles en formo de lance ate' 10 ans de lampondo 1 1,5 an fe

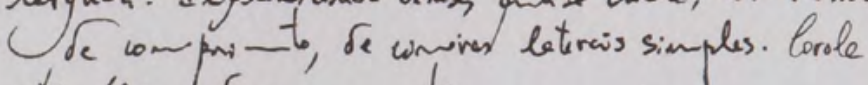
at $10 \mathrm{~m}$ do compexion he, en forne Se funil, brance a agubet. Exches:va das enuostas do rulcas de fogo. Emuaturada freprivinite un seloco cobertites de bopils ma emosh of vulco (a partir de $1800 \mathrm{~m}$ de altitude.

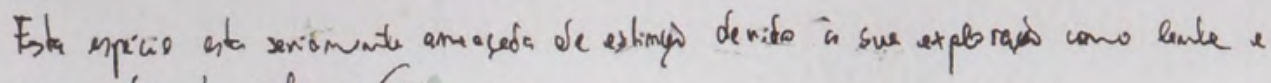
conso atiments pelas carras. 

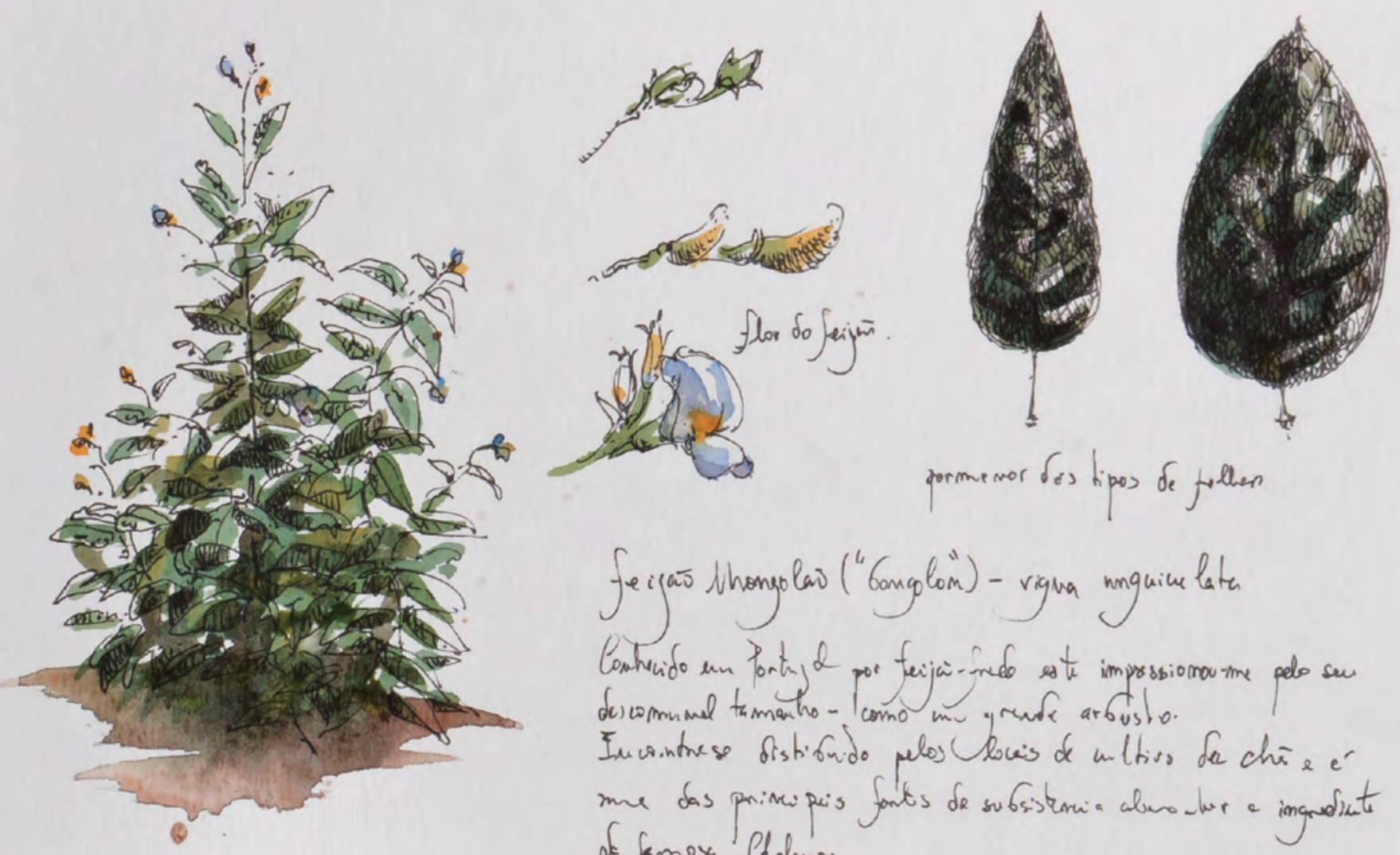

pormenor fes tipos de fellen

feigas thongolas ("Gonglonn) - vigua unguimelater

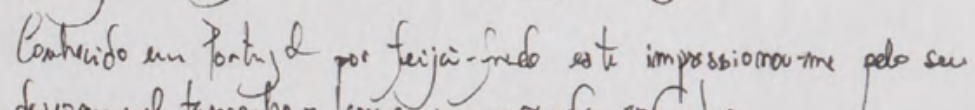
descomumel tamanho - como mu grave arbusto.

Incointrese distifudo plos locies de unltivo de chi a é

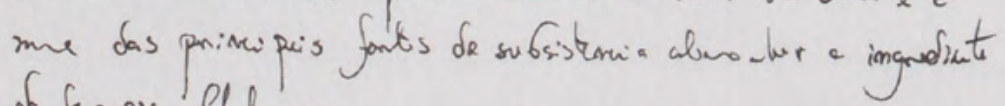
of famoser Clachupen.

JA 


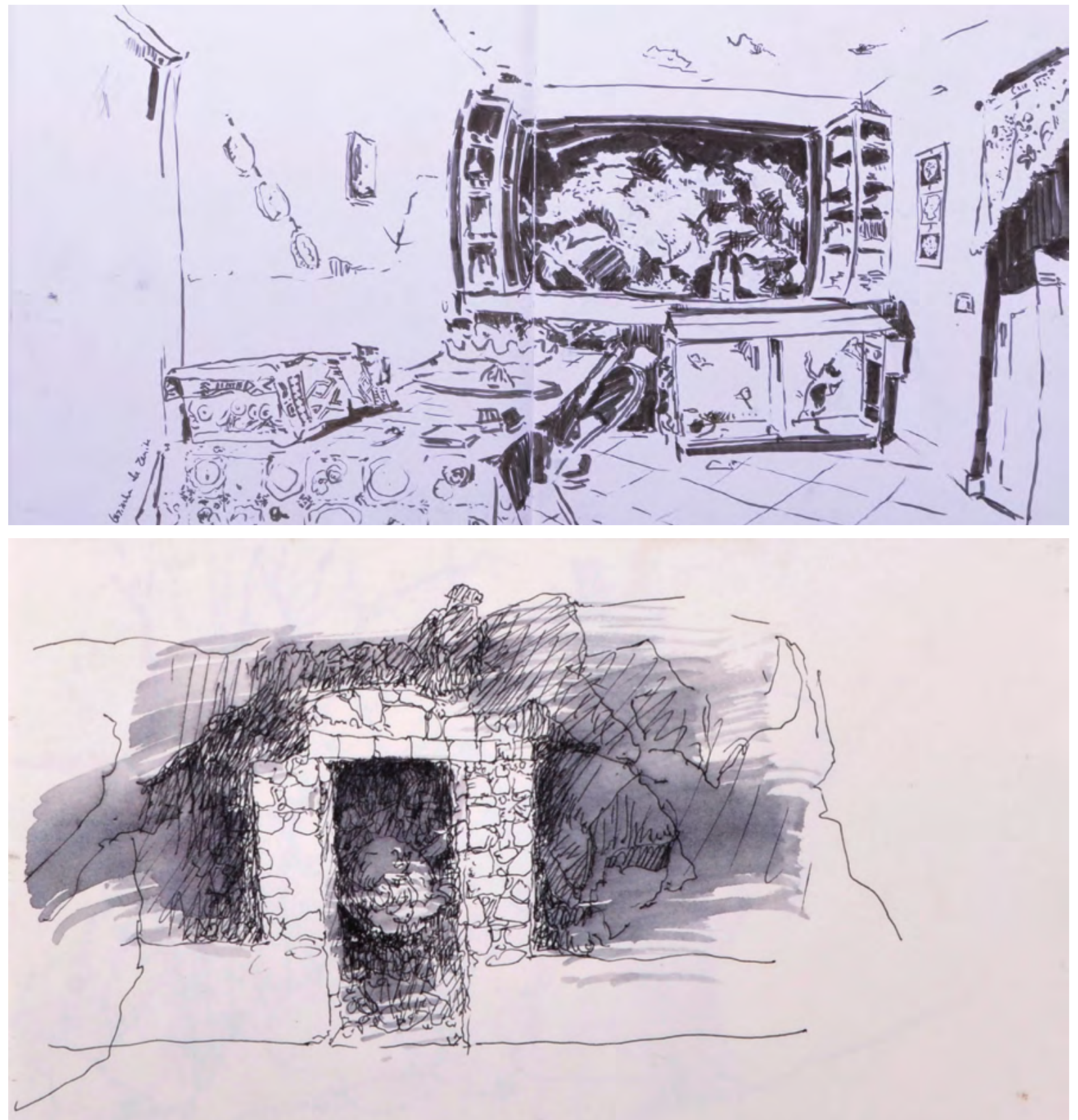



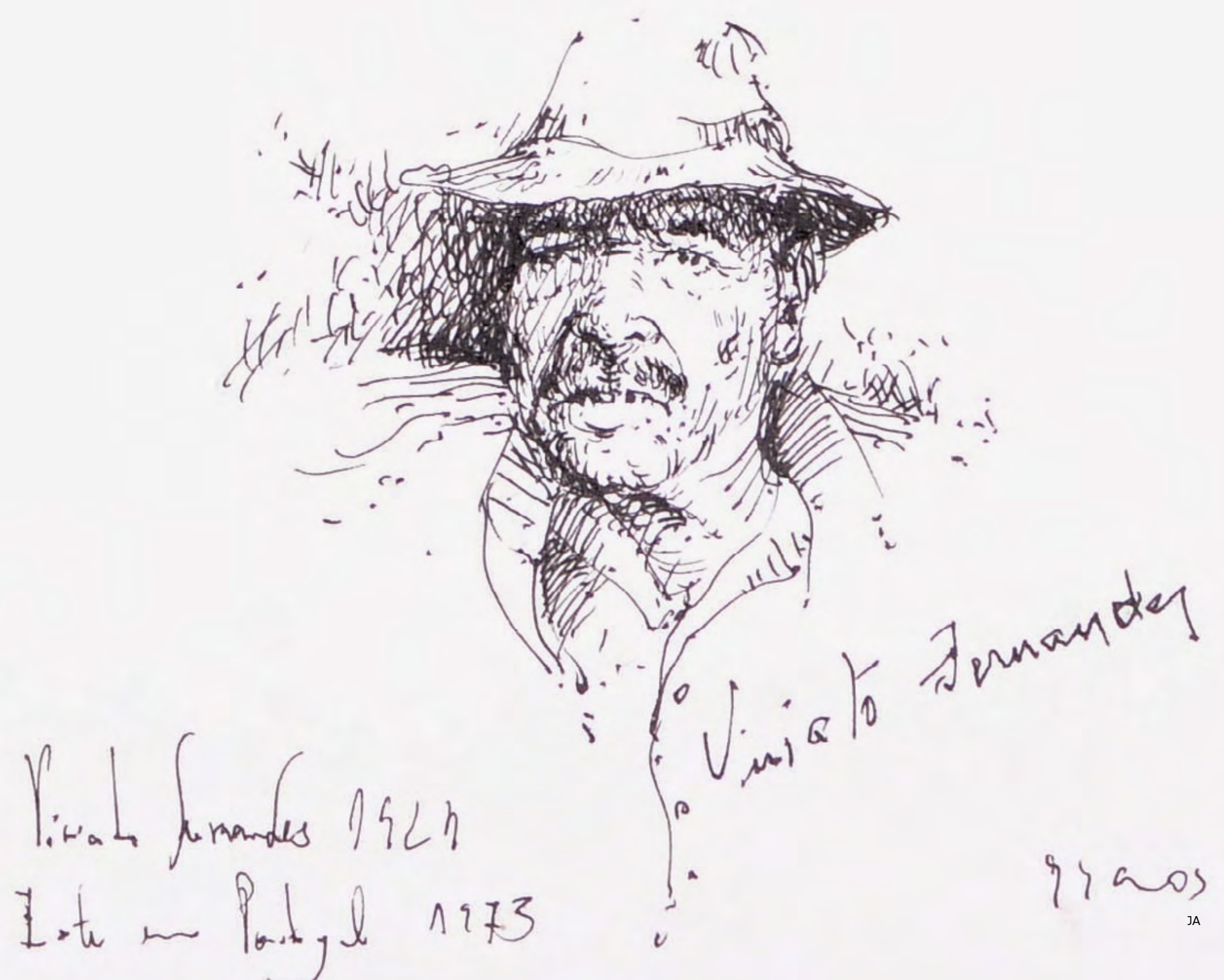




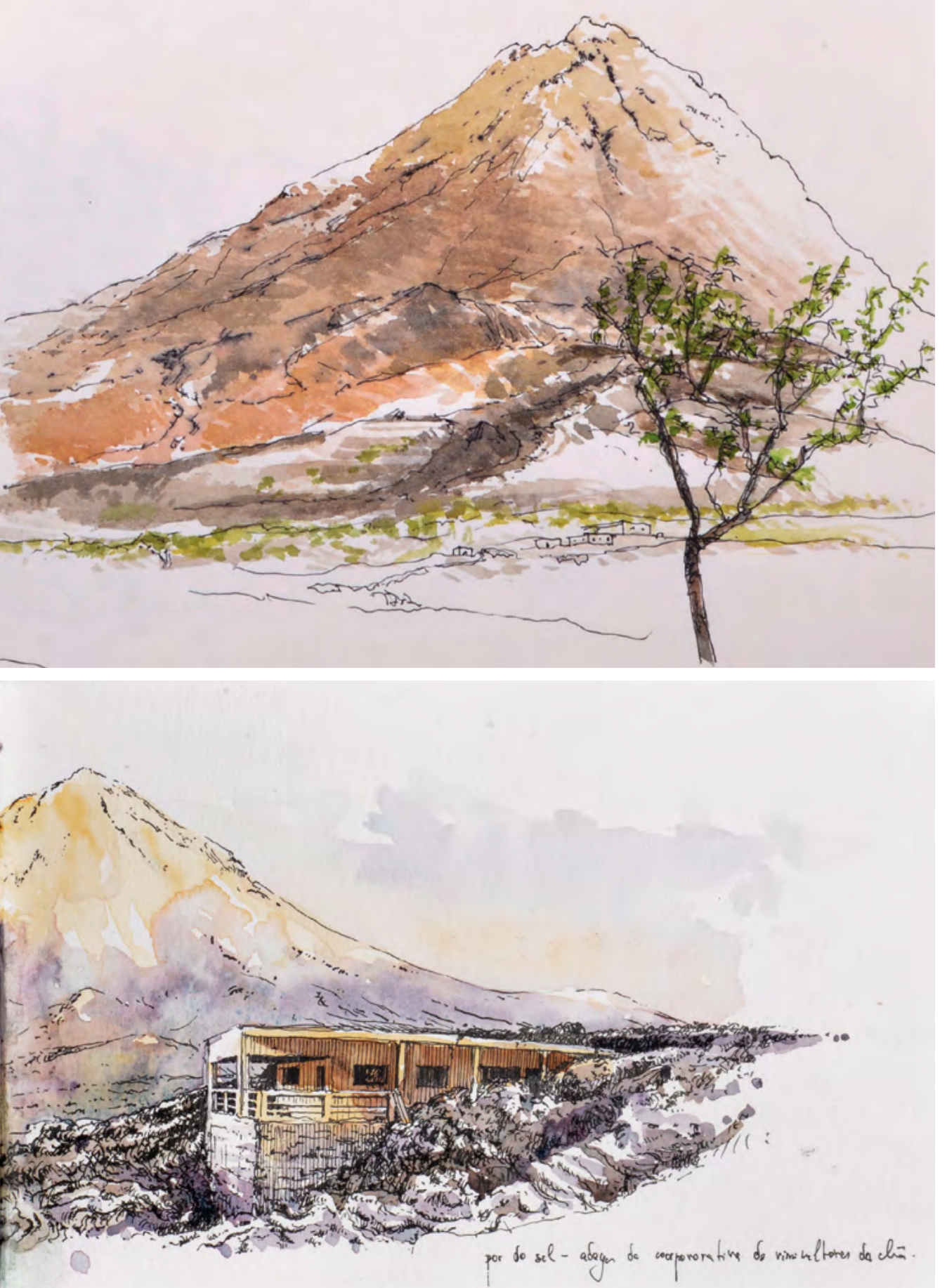

voul año

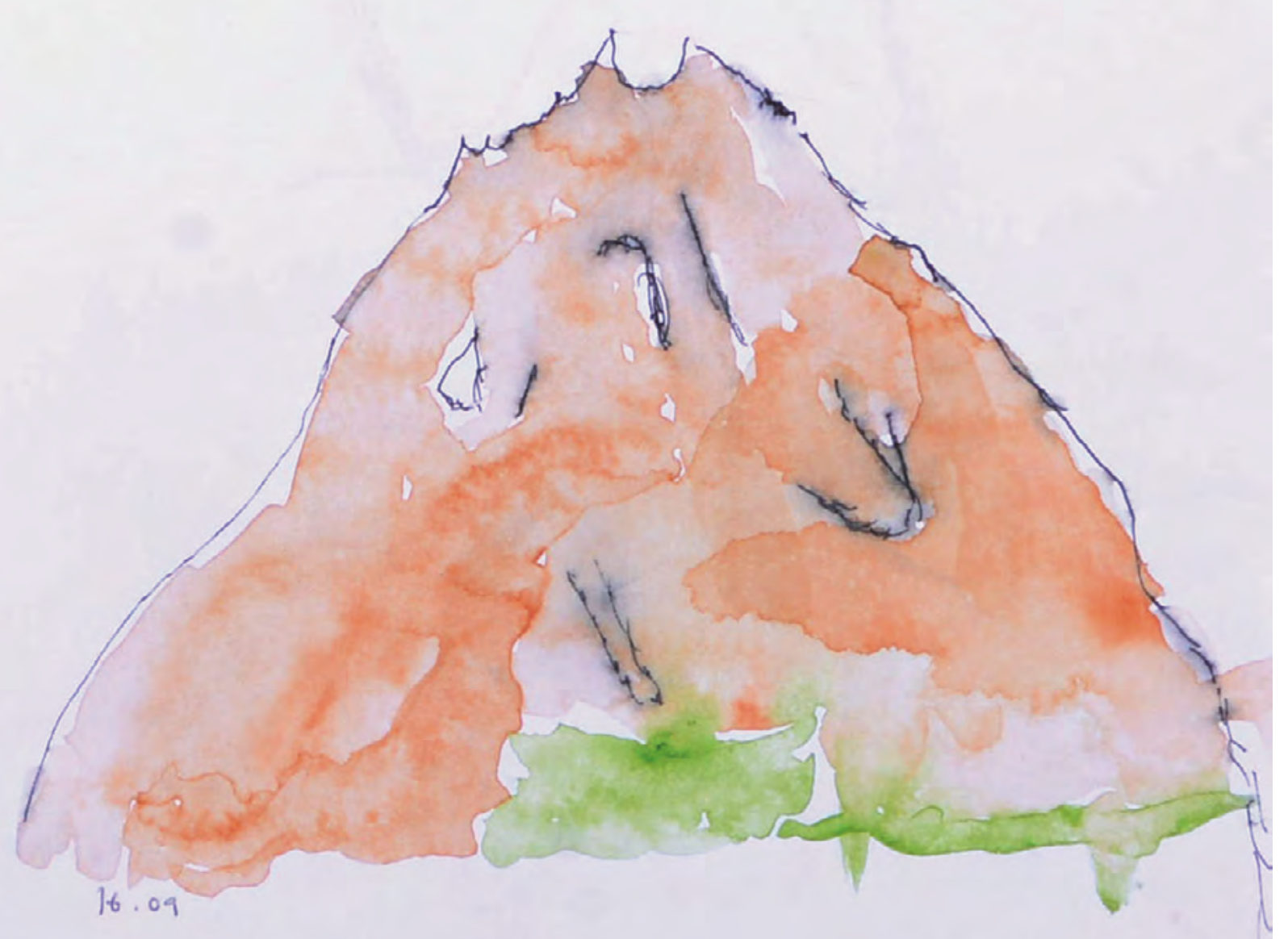





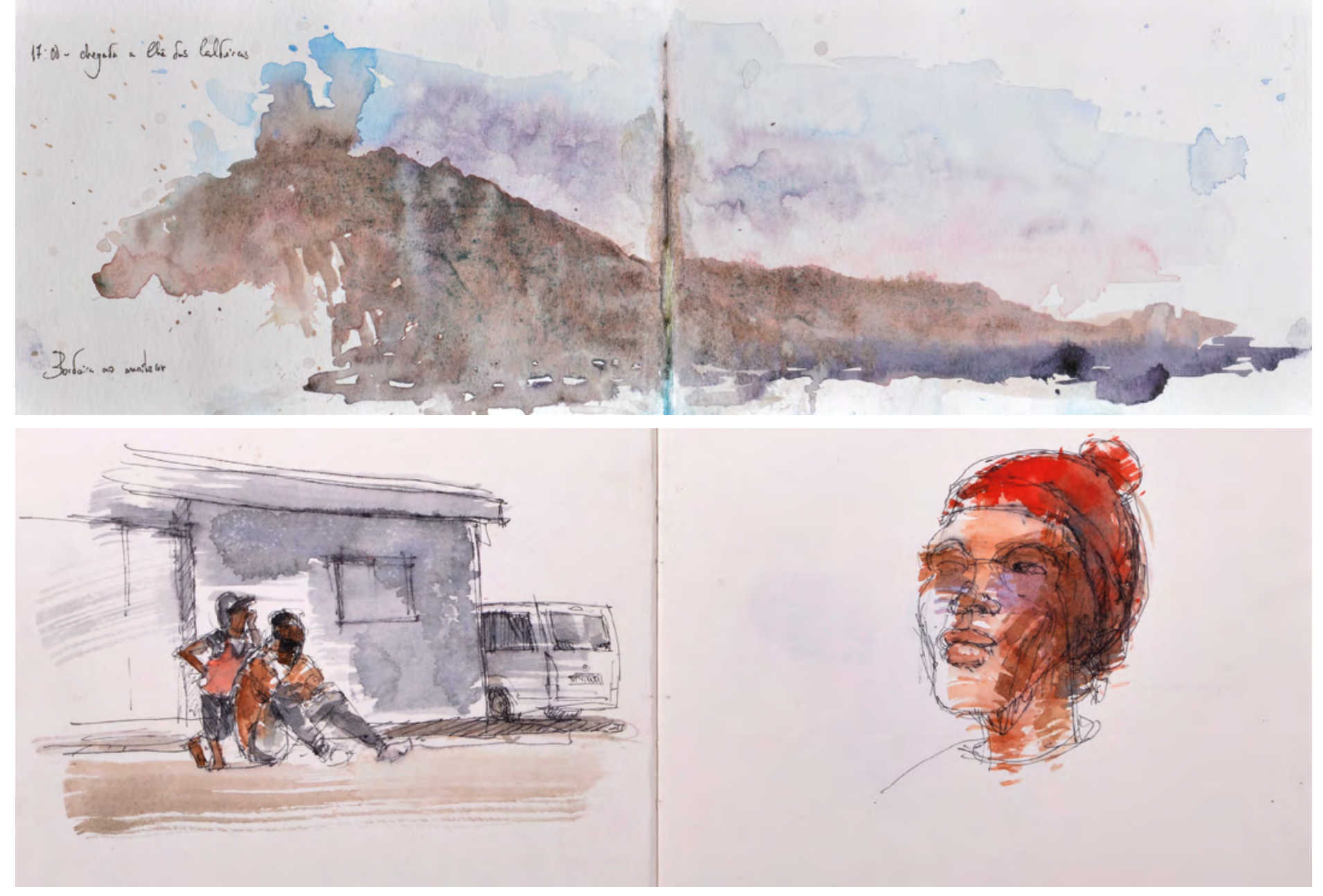

MA 


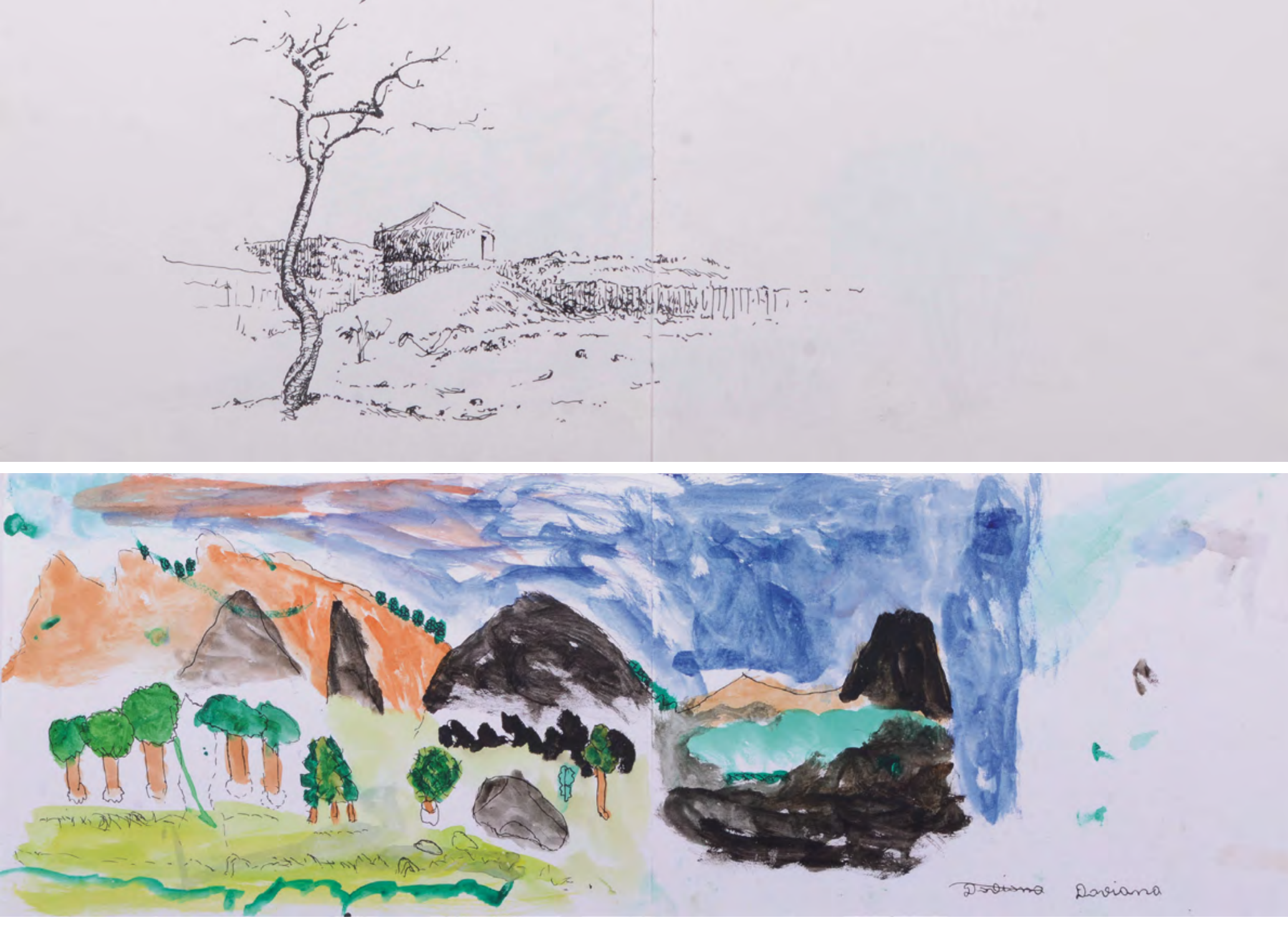


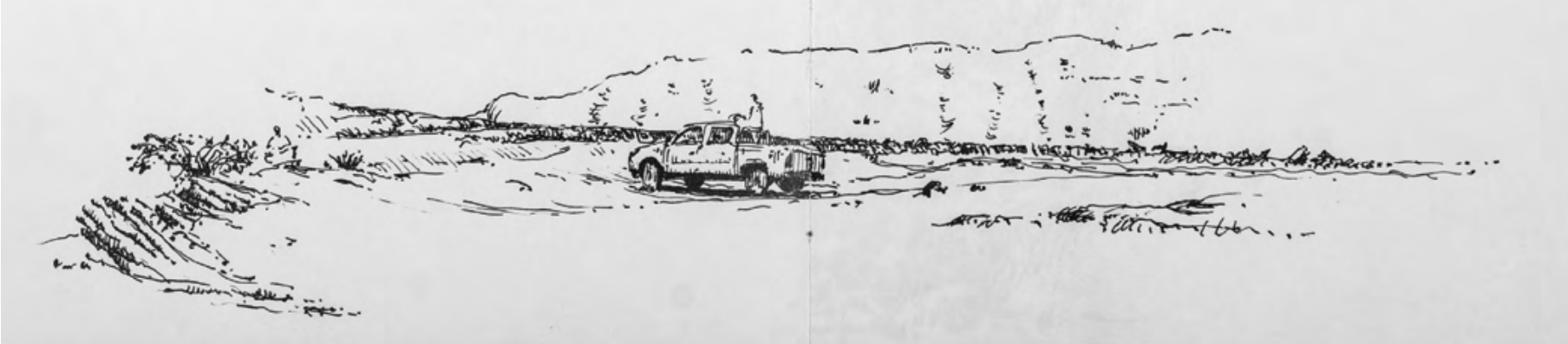




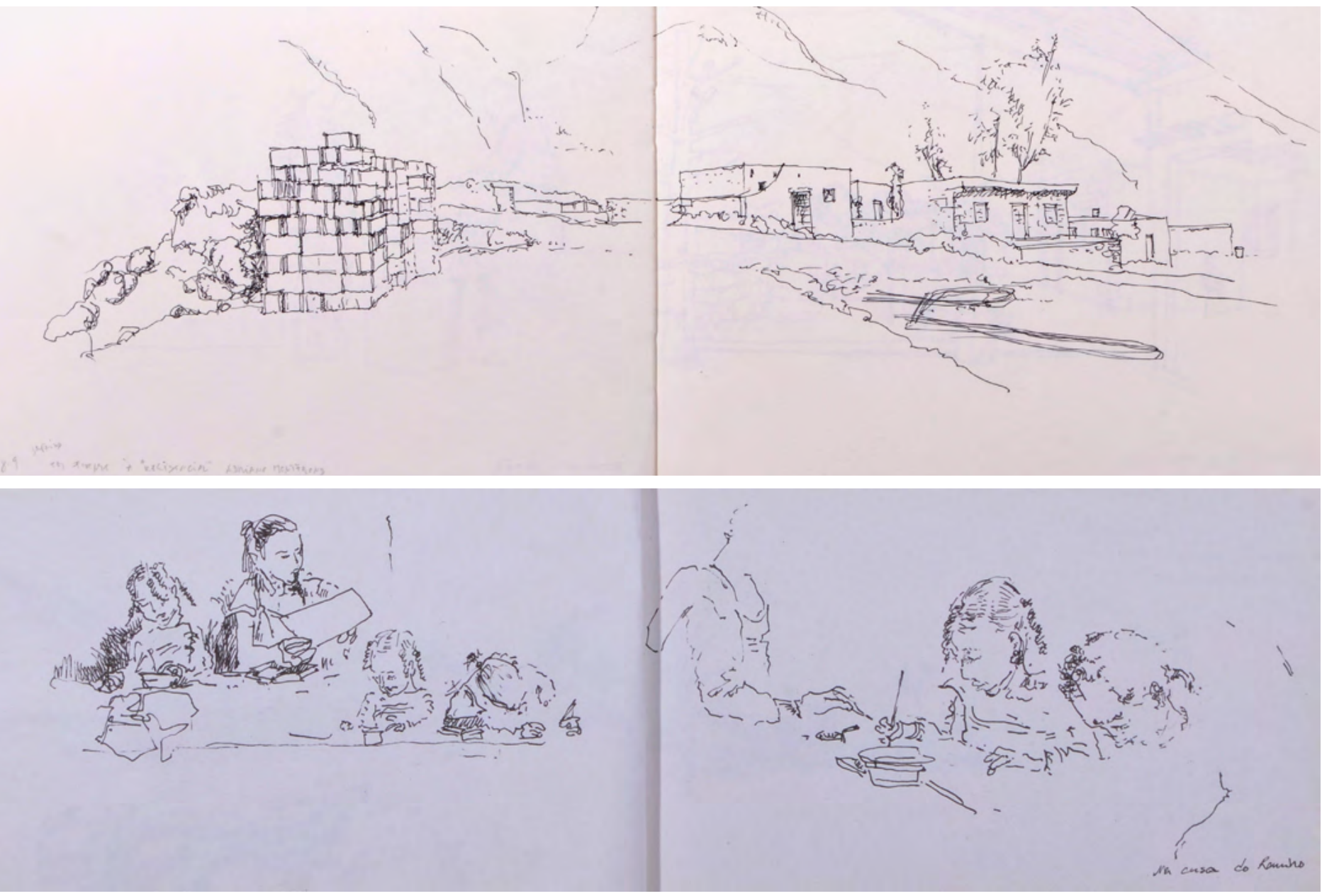









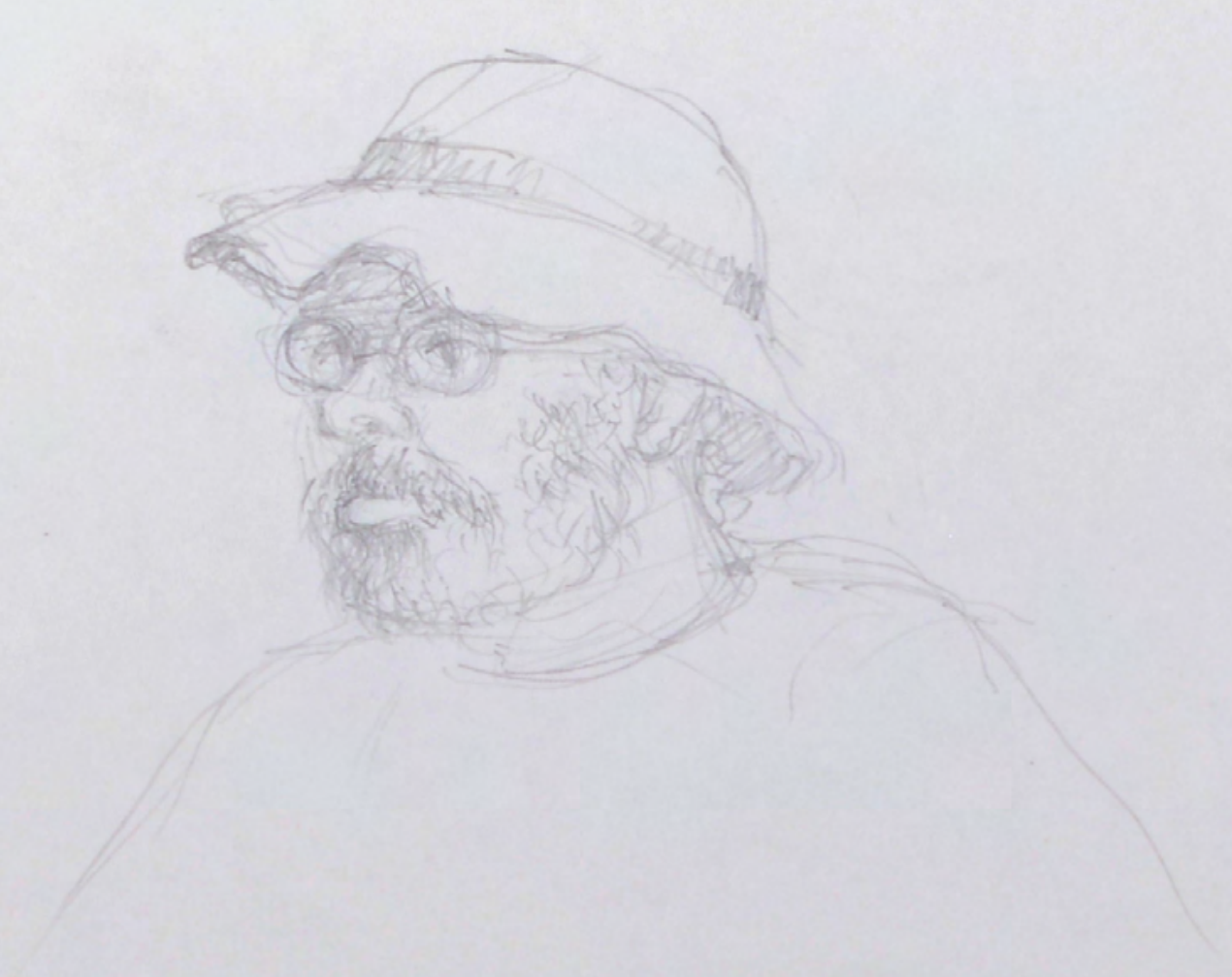


- 4 ere 


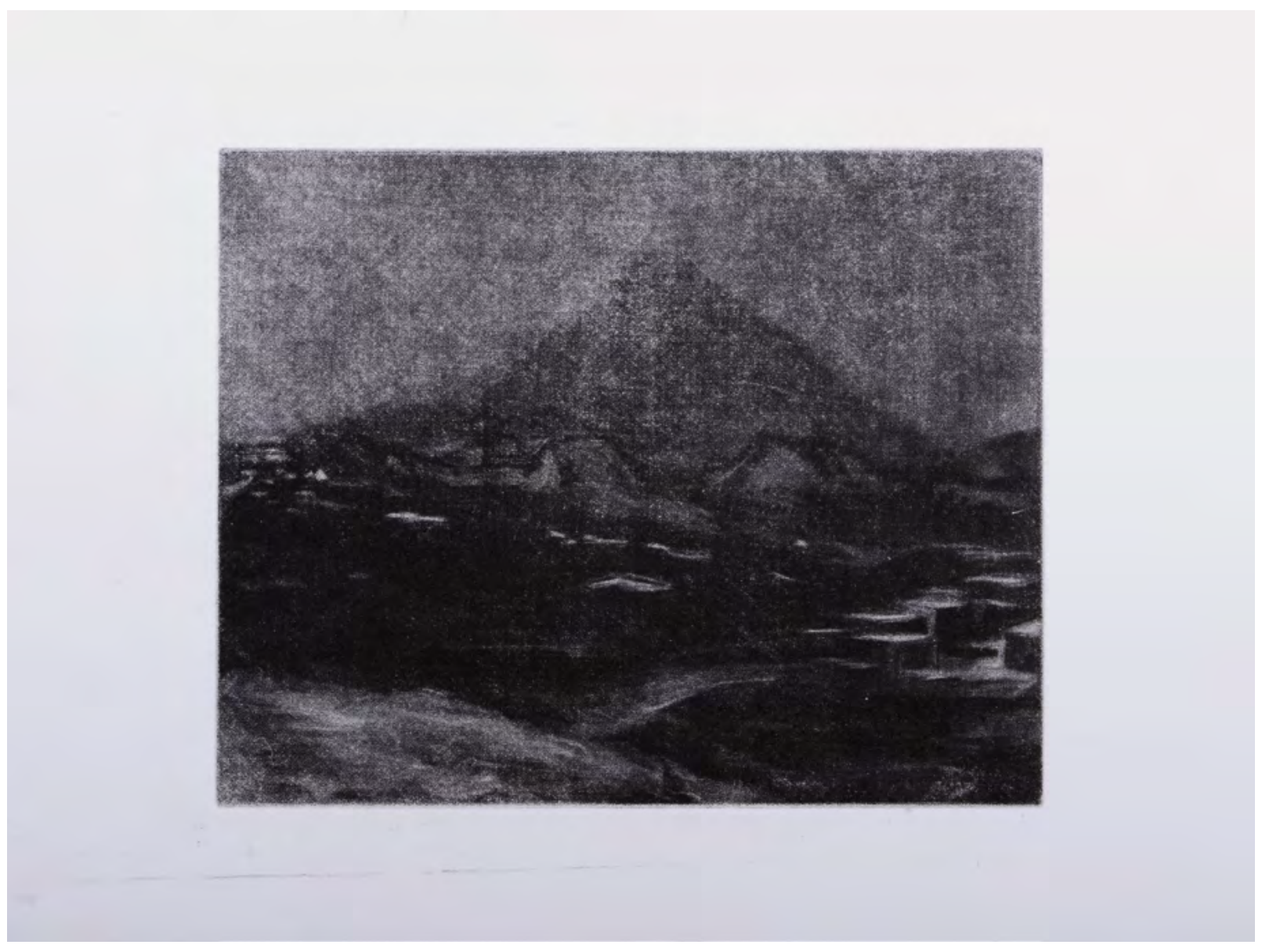











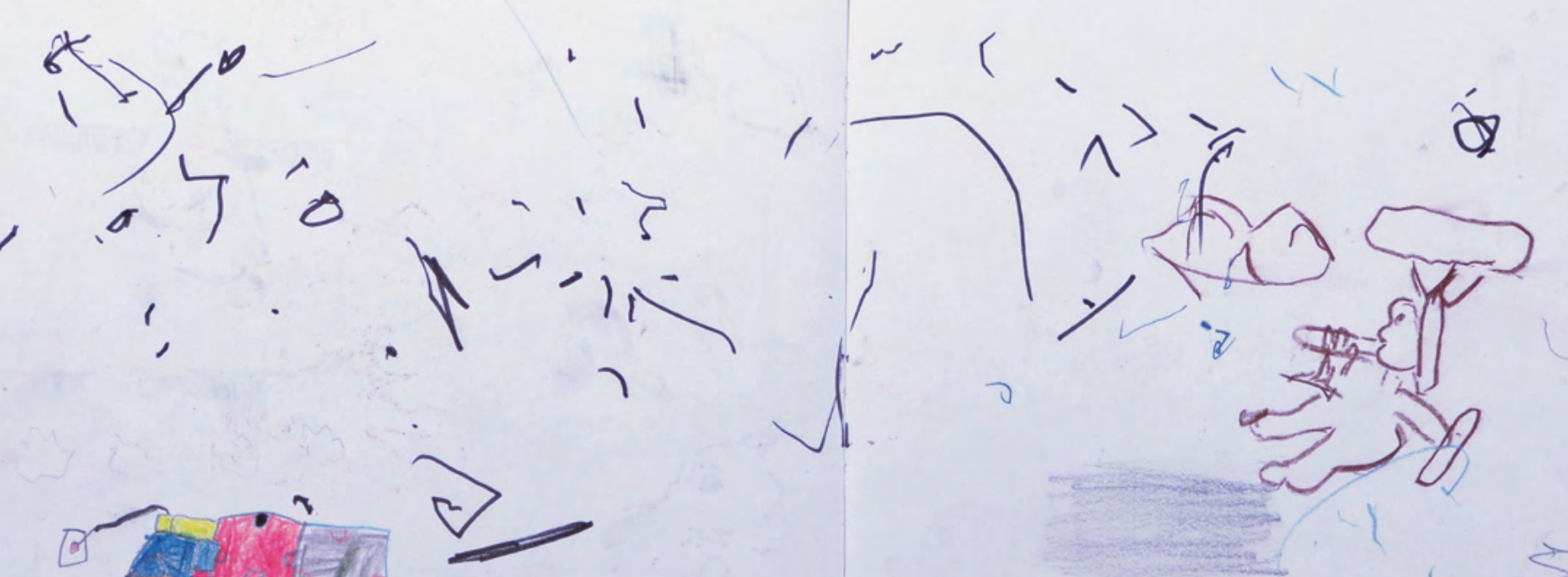






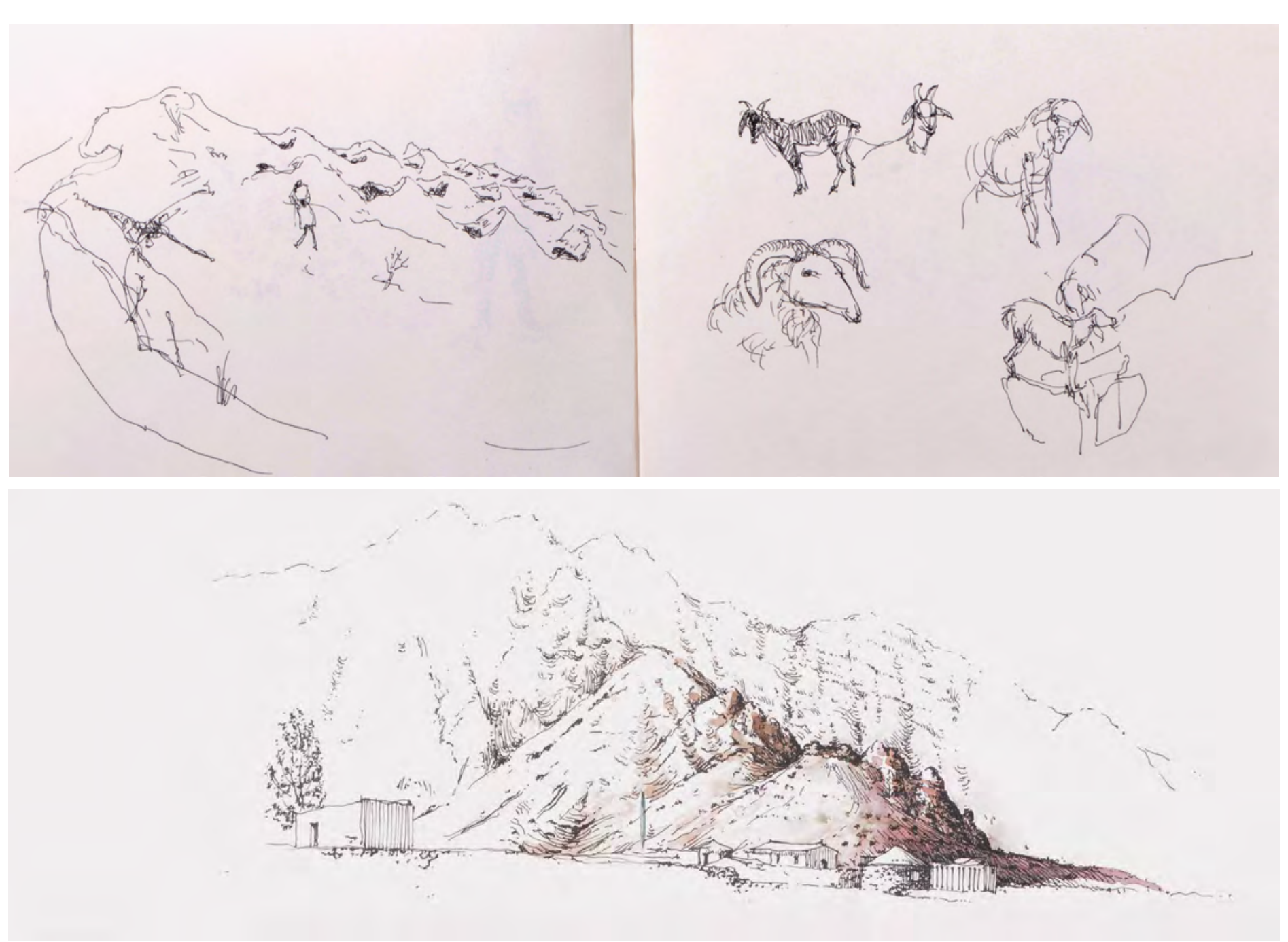




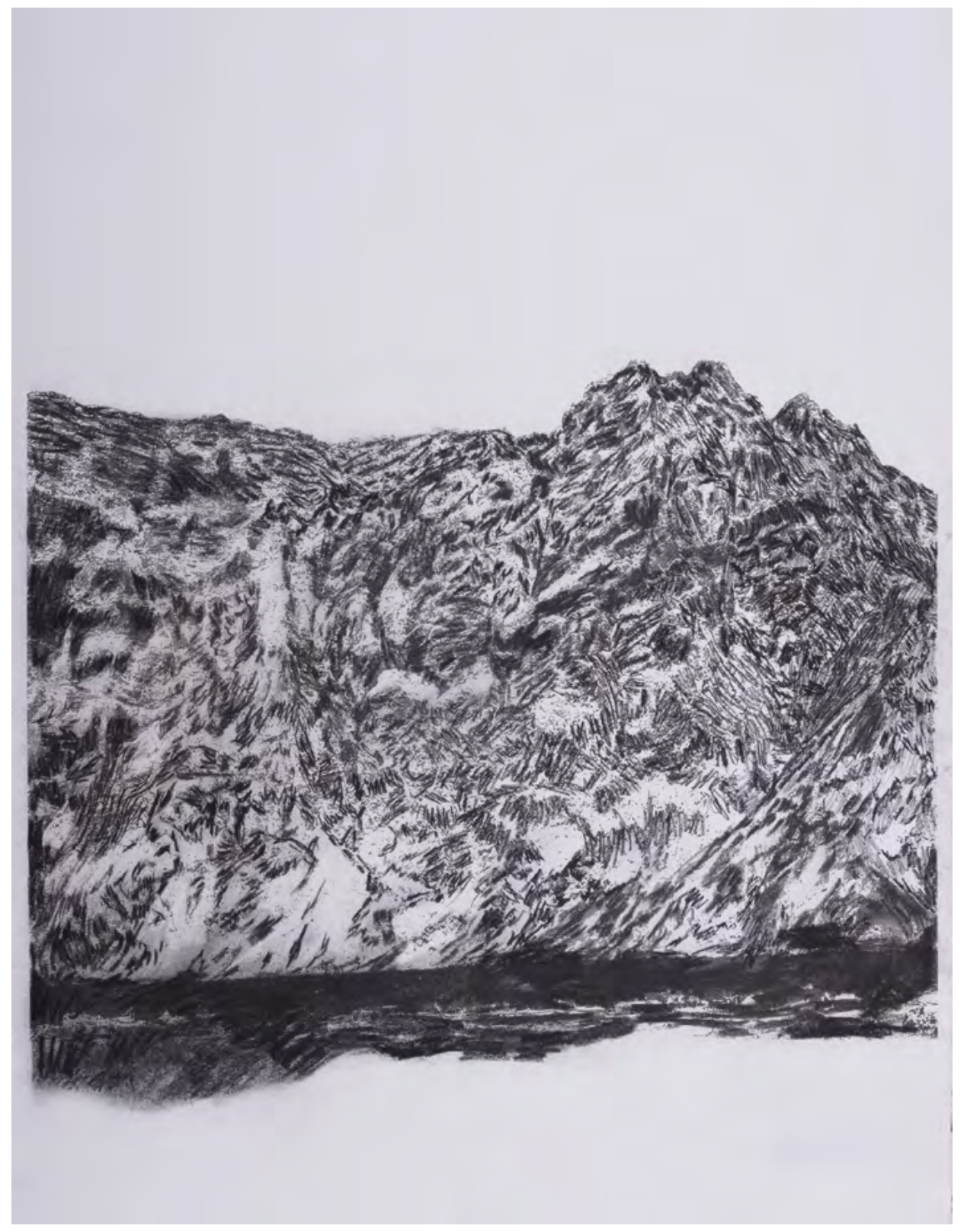





Cana de cabo vebde havra muitar mas agoro sie vir 1 e no meio da lava.

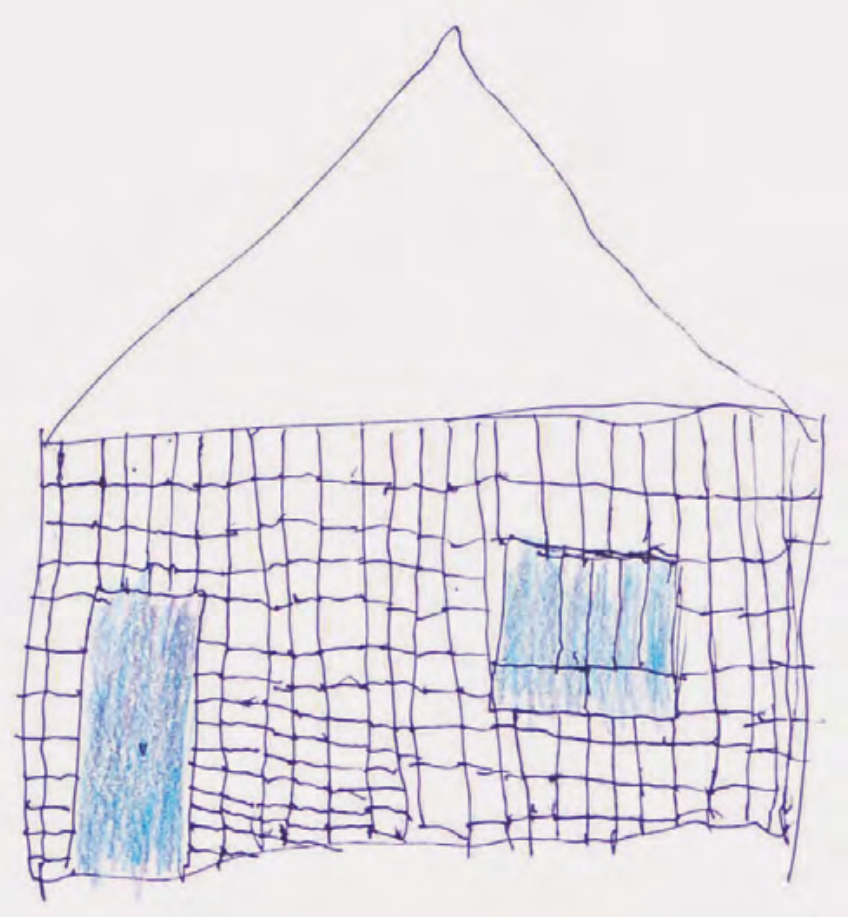

17. 09

funco 


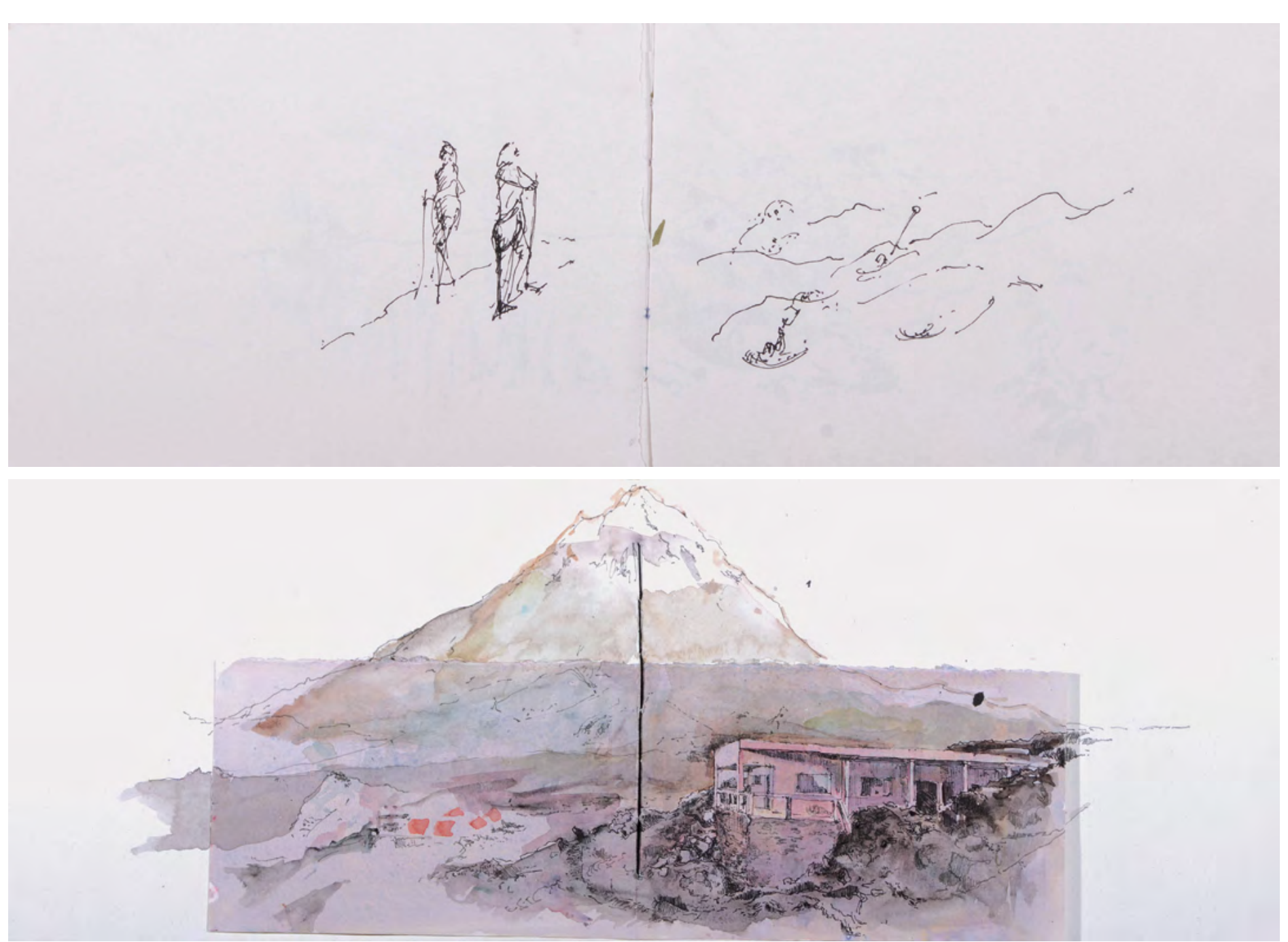




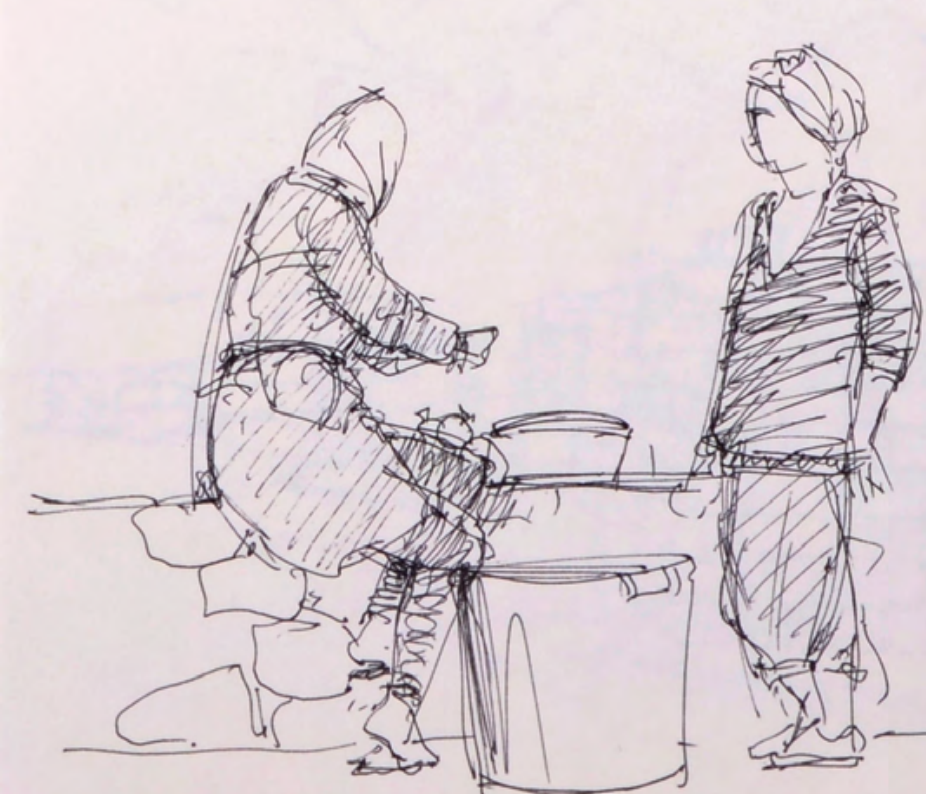




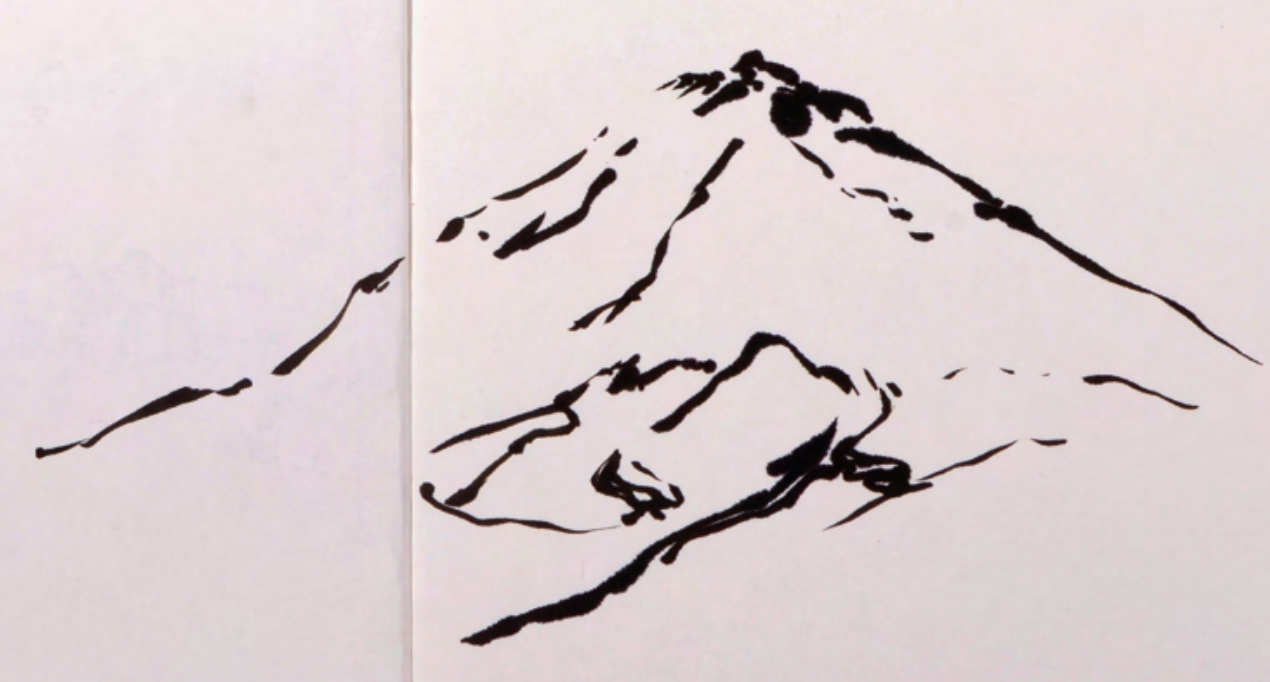



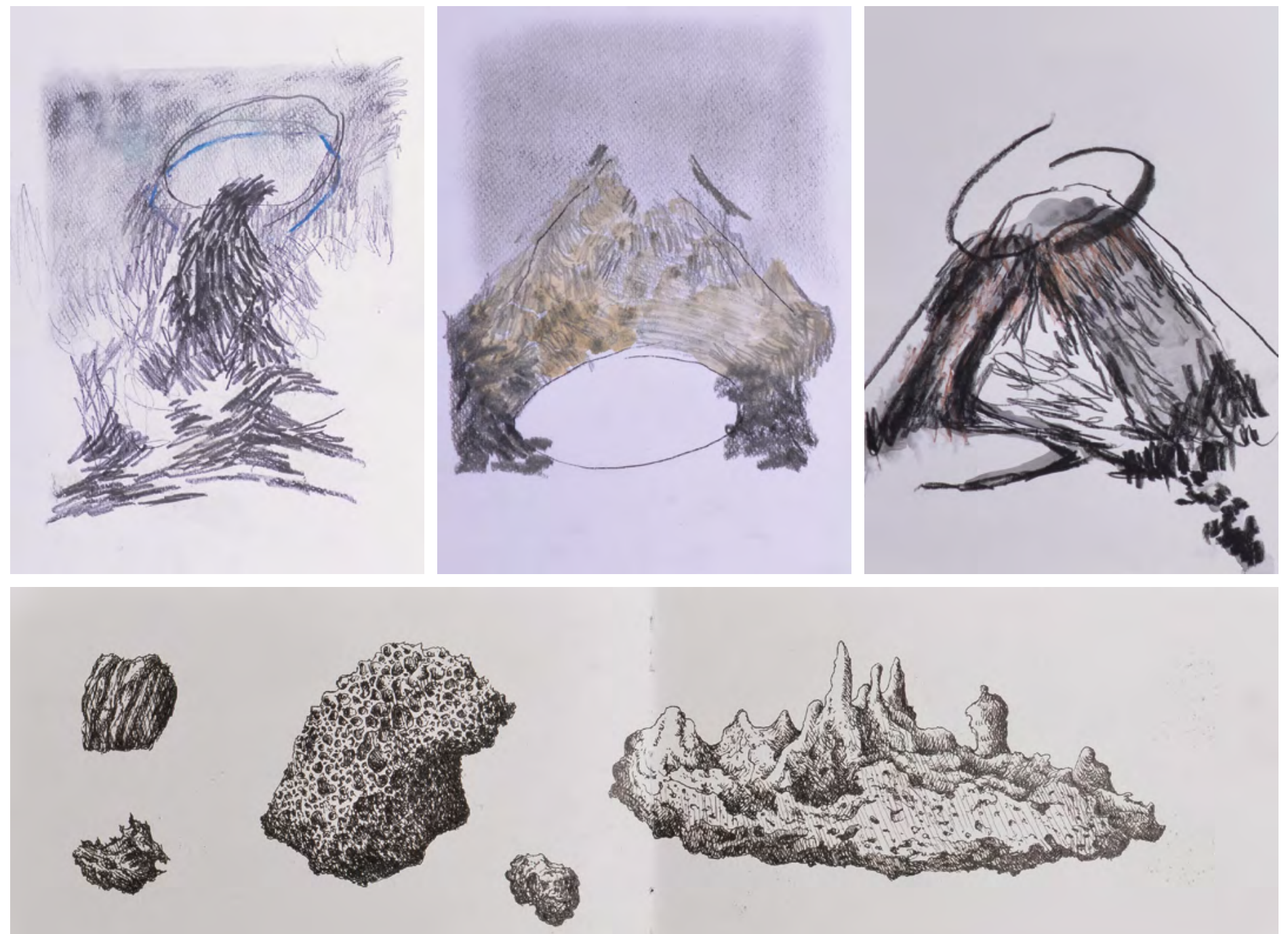
E
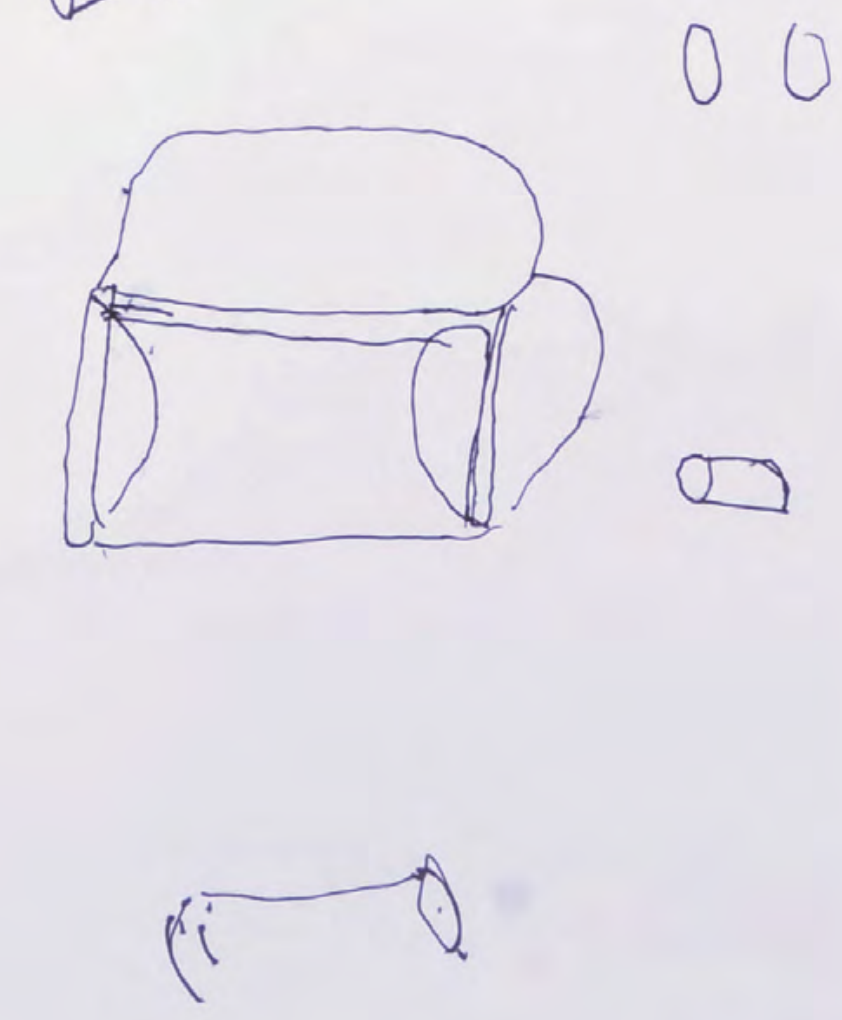


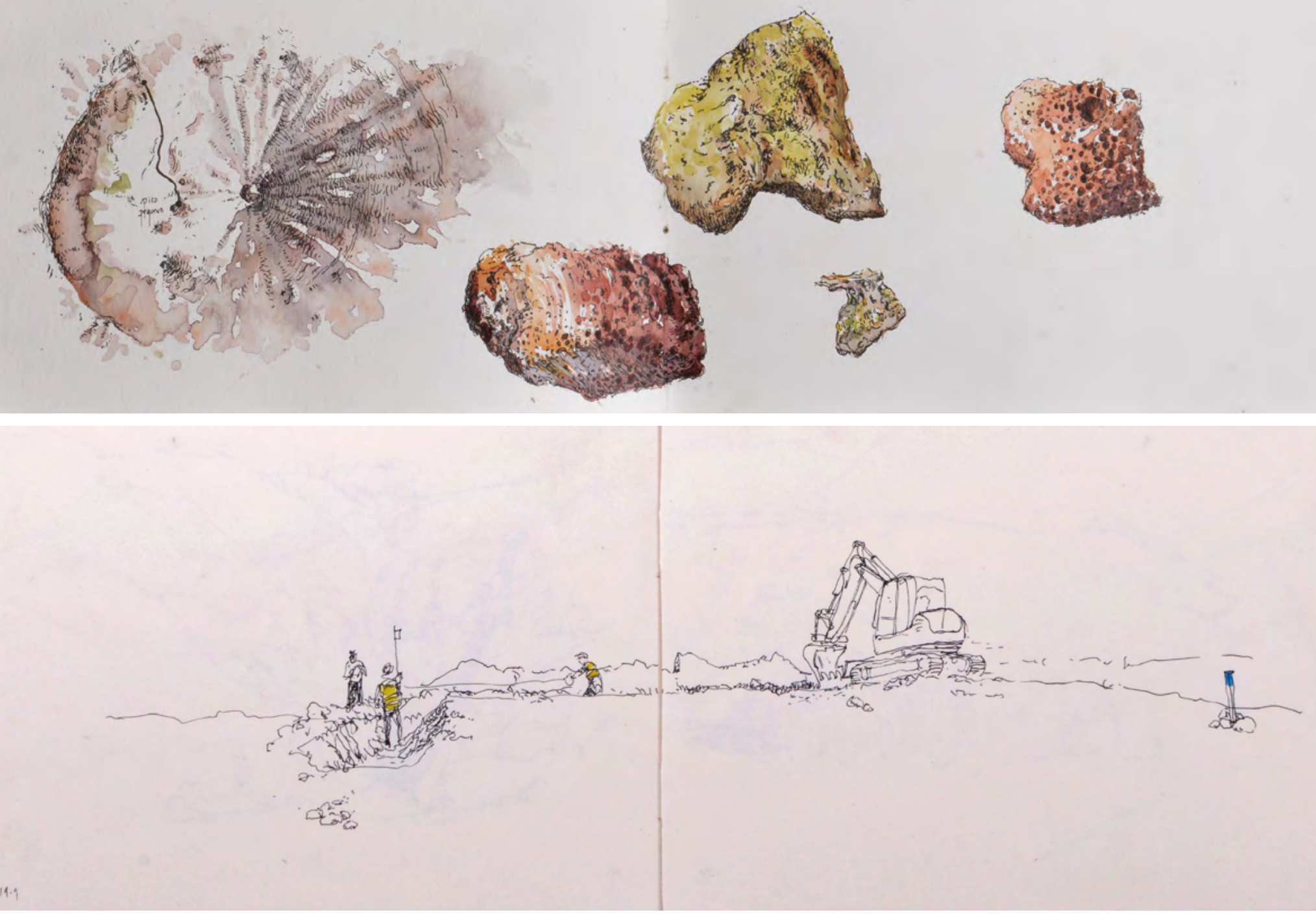


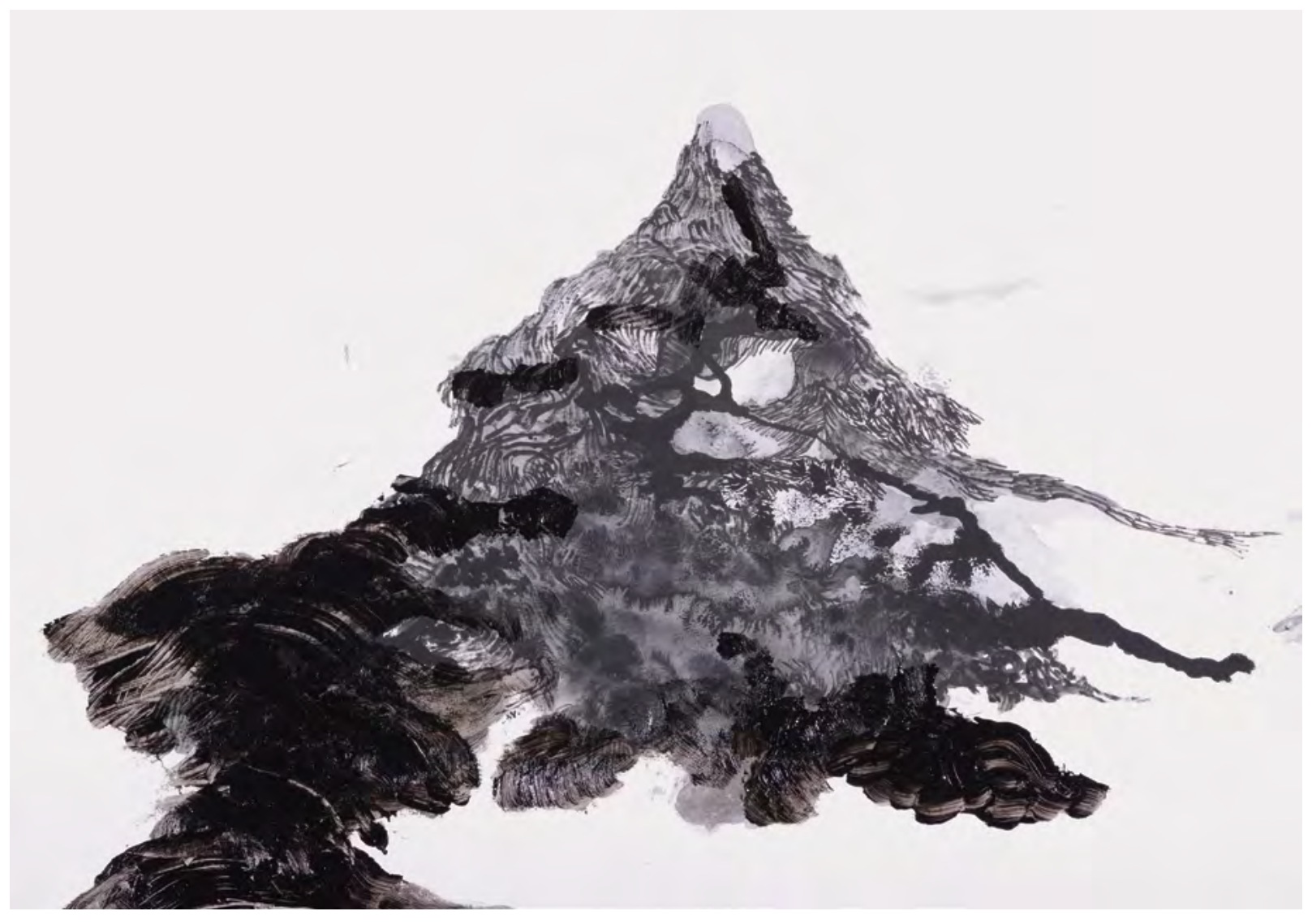








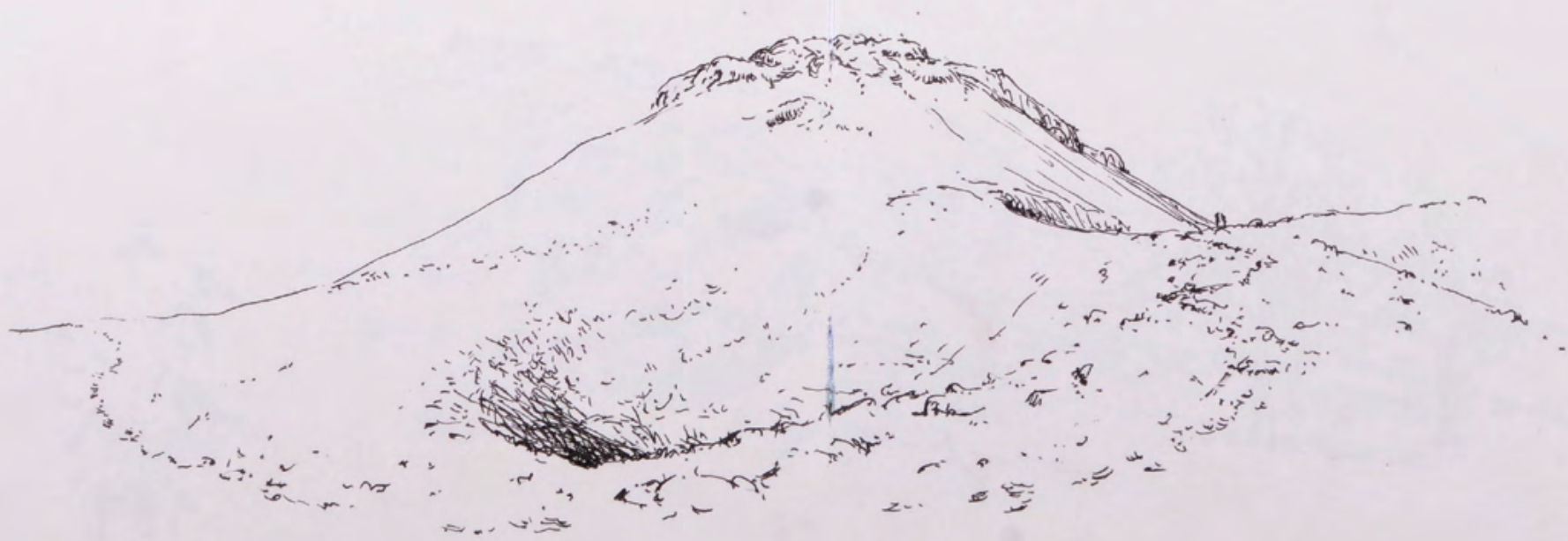




$$
8 \text { so }
$$





\section{Esquissos de um Vulcão}

Durante a subida da bordeira, os inesperados solavancos da hiace deixavam-me com a caneta no bolso. Fiquei apenas a ver.

As últimas chuvas tinham vestido parte da ilha com um manto de verde, porém à medida que subíamos esses verdes davam lugar a ocres, e estes a um escuro que tornava qualquer caminho incerto. Subitamente, ao contornar uma escarpa viramos todos a cabeça na mesma direção e ficamos imóveis a vê-lo - aí soube que tínhamos entrado em Chã.

A névoa que se erguia do magma seco, ainda quente da última erupção, cortava por vezes o olhar fixo que mantínhamos com o cume do vulcão.

Ainda hoje não entendi bem o que senti. Era um misto de fascínio e de receio. Sabia que aquele chão que pisava estava bem vivo. Ignorar a força que aquele lugar nos provocava era impossível. Éramos pequenos.

Lembro-me que após a entrada na cratera andamos alguns minutos sem nos depararmos com algum sinal de vida. Os pneus eram o único som que se fazia ouvir.

Conforme avançámos começaram a surgir entre as poucas plantas rasteiras algumas vides que anunciavam e denunciavam a mão do Homem. E por falar nele, começavam por esta altura a destoar no negro da paisagem algumas formas geométricas planas telhados à deriva num mar escuro e estagnado.
A comunidade de Chã já se habituou, ao longo dos séculos, às metamorfoses da paisagem e à efemeridade dos seus lares. O Fogo acorda de vinte em vinte anos cobrindo parte do passado material e imaterial daquela gente.

O tempo e as lavas levavam a população de Chã a improvisar o futuro. Mas o passado ainda era bem visível. Poucas eram as casas que não estavam trespassadas por braços de lava. Recordo o pequeno almoço em casa da Zenita - era tomado de frente para um muro de magma parado na entrada para a sala.

Por mais bizarro que pareça, eles não veem o Fogo como um inimigo. É muito peculiar a sua relação. As cinzas negras que lhes cobrem as casas são igualmente a fonte, em constante renovação, de nutrientes das suas vinhas, hortas de subsistência e plantas endêmicas, dispersas pela caldeira. Não se imaginam a abandonar Chã. É difícil explicar ou até entender a força e a robustez dos pilares que sustentam aquela comunidade - são a prova mais pura de amor à terra.

Todas as manhãs, quando saímos à rua, ecoavam na cratera entre algumas gargalhadas de brincadeiras, serras e ponteiros que talhavam novas pedras para as casas que se iam reerguendo.

A resistência leva-os à reconstrução e ao refazer de todo um presente, por mais curto que ele pareça, em cima do passado. Foram estas mesmas relações e correlações que fomos tentar entender, se é que é possível, com um lápis na mão. 
No início tive dificuldade. Chã consegue pôr à prova, a qualquer nível, quem por lá passa.

Quanto mais desenhava mais constatava que os meus hábitos de representação quase que se haviam tornado inúteis. A perspectiva deixou de estrangular o espaço e os contornos dançantes das caras que esquissava no autocarro foram trocados por picos desnivelados, que se assemelhavam ironicamente aos desenhos de um sismógrafo.

O desenho começava a entender o espaço. As manchas negras começavam a ter o seu próprio caminho. No fim já começava a ver melhor. Estes eram desenhos que tentavam, muitas vezes de forma infrutífera, não copiar ritmicamente as formas, mas sim conhecê-las na sua individualidade.

Podemos dizer que o desenho entrou aqui como uma ferramenta de ligação entre mim e o local, entre mim e os outros. Encontrava-me, umas vezes a riscar obsessivamente o negro do magma e outras contornando rapidamente uma planta ou o velho sorriso do $\mathrm{Sr}$. Fernando que conheci no pátio coberto do Ramiro.

O registo jogava com as dimensões, uns à escala real, com mais detalhe, mais atenção (pedras, partes das plantas, etc.) outros que tentavam resolver a imensidão do espaço a esquissos de contorno rápido.

Aliás, o facto de estarmos sempre a percorrer um local imenso e, por vezes, invariável levou-nos inevitavelmente a recorrer a uma outra faceta do desenho: a cartografia. Tanto no trilho para Monte Velha, como ao Pico Pequeno, o desenho como visualização do percurso que fazíamos era essencial para a nossa localização e entendimento sobre o espaço. E por nele falar, apesar de o podermos reduzir a tons cinza, o simples ato de olhar para o chão maravilhava-nos: dependendo da quantidade de oxigênio ou ferro nelas presentes, as rochas podiam ir do vermelho, ao azul ultramarino ou ao amarelo enxofre.

Era bom perder-me a desenhar (por vezes literalmente).

As memórias que de lá trago são imensas e infelizmente, ou felizmente, não consegui desenhá- las todas, mas ainda gosto de recordar o sabor do seco do manecon, acompanhado por uns rabiscos apressados e já fluídos, embalados por uma talaia baxo que ecoava por toda a caldeira. 


\section{Desenhar Chã}

No princípio era o desenho. Depois o verbo.

E assim se fez Chã.

Há cinco milhões de anos o vulcão deslizando para o mar, desenhou Chã. Fez tsunami. Mais tarde, Pico Grande, mais tarde ainda, Pico Pequeno.

Depois de mais tarde ainda vieram os homens. Na lava já quase fria plantaram vinhas, que de cepas secas e retorcidas brotaram folhas exuberantemente verdes e bagos que se fizeram uvas. Suculentas, doces: projecto de vinho, projecto de vida. Descobriram, eufóricos: plantar é desenhar! E nunca mais pararam de desenhar. Depois vieram as mulheres, desenhou-se meninos, muitos meninos, que desenharam outros meninos.

E assim se fez Chã.

Com desenho, sempre.

Um dia, era novembro, Pico Pequeno olhou cá para baixo. E pensou: vamos desenhar Chã, de outra maneira. O futuro pode ter outro desenho. E "furou". Deu suspiro fundo. De suas entranhas não veio ódio nem raiva. Apenas lava, serena, deslizando, fazendo caminho, riscando aqui, apagando ali, o que era para apagar. Para voltar a desenhar. Não para esquecer. Mas para lembrar. O desenho não pára aqui, disse Pico Pequeno: o desenho é sempre, o desenho é futuro sempre aberto, em "perpétuo movimento"... assim como o magma no fundo do coração do mundo.

Pensava Pico Pequeno sob olhar atento, maternal, de
Pico Grande enquanto a lava líquida, doce, incandescente, impávida, vinha escorrendo encosta abaixo por caminhos que escolhia e outros que desenhava.

E assim, era novembro, e tudo recomeçou. Onde havia casa em cima do chão, ficaram lembranças enterradas de vidas e de casa que foi e que os meninos passaram a desenhar, sonhando sua nova casa, sua nova vida. Onde havia presente ficou futuro, onde havia chão de vinho, ficou basalto. Duro, cristalino, que, não resiste à pesada marreta da incomensurável determinação de desenhar Chã. Hoje!

Na Chã desenhamos todos. Todos os dias, sempre: os que estão e os que vêm. Riscamos acordados, mesmo dormindo; na parede, no chão, no ar, sobre a lava ainda fumegando. Na cabeça e no coração, na sombra da nuvem pairando no topo de Pico Grande, na encosta da Bordeira onde todos os picos da vida se desenham com a luz do amanhecer difuso, em crescendo, lento, até cair, feliz, no desamparinho que anuncia amanhã...

...até um novo novembro. Que não será tão longe assim. Até que Pico Pequeno pare para olhar o que foi desenhado.

Leão Lopes 


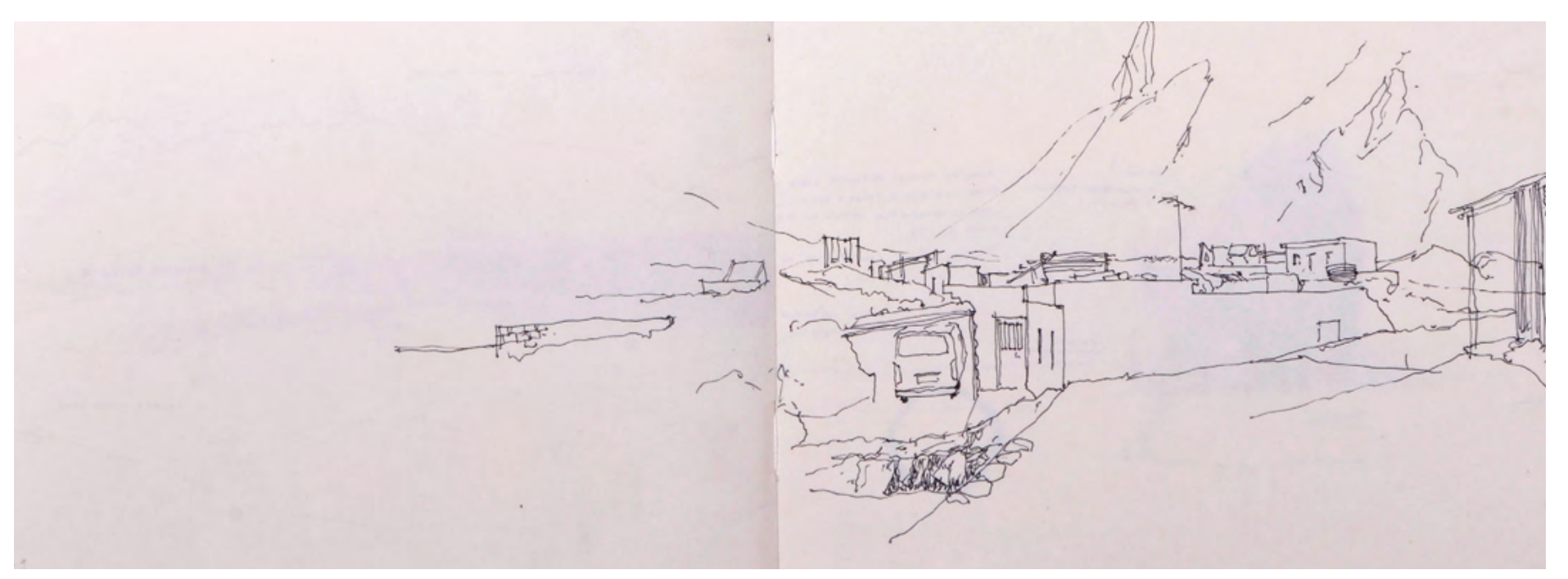




\section{Chã das Caldeiras: notas/fragmentos de um envolvimento}

0.

"Quem traduz literalmente é um falsário, quem acrescenta alguma coisa é um blasfemo"

Antigo ditado rabínico

1.

Perante um "problema".

Fomos convidados para irmos a Chã das Caldeiras desenhar. Mas porquê desenhar? Mas para desenhar o quê?

A destruição? A lenta recuperação? O emergir da vida? A imponência da "paisagem"? A (im)potência das pessoas? A estranheza do lugar? O calor emergente da terra? O silêncio da manta de lava? A negrura dominante? A latência de nova destruição? A resistência das pessoas, dos animais, das plantas? A presença de uma videira num chão de cinzas? $\mathrm{O}$ visível?

O lugar foge às convenções, aos hábitos e ao habitual, afasta-se das certezas "pitorescas" da imagem. Chã não é "paisagem"!

Desenhar como? E, perante o sítio, este sítio, desenhar para quê?

Para quê as imagens?

2.

Este é um tempo do excesso das imagens.

O actual excesso de oferta e (ab) uso das imagens produz a inevitável diluição da sua relevância: a proliferação quantitativa das imagens reduz a sua capacidade de nos envolver, de nos tocar. Paradoxalmente (e higienicamente), perante a maior quantidade das imagens, infinitamente menor é o seu poder, menos elas nos afectam. Não somos selectivos, somos adormecidos.

Neste mundo envolto e coberto de imagens fotográficas - esse poderoso processo de transferência e substituição do (confronto/conhecimento do) real pela imagem - deixamos que a máquina fotográfica construa a articulação da imagem (o seu sentido)... já não vemos, já não temos tempo para ver. Confiamos e delegamos nos dispositivos fotográficos a nossa memória, a nossa relação empática e afectiva com o real. Construímos assim, não um processo de contemplação, de inquirição do visível, mas um afastamento e uma distância. Construímos imagens de um mundo sem a vivência do seu tempo e do seu lugar. Já não vemos.

3.

Há assim uma crise do "ver" como consequência da explosão quantitativa das imagens: o excesso das imagens neutraliza a sua atenção, a sua importância, a sua relação mediadora do espectador com o real. Todas as imagens se parecem, todas as imagens se assemelham, provocando uma dormência perante a quantidade das imagens, uma inércia perceptiva. Mas, como nos diz Fernández-Savater', "O problema não é (...) que vivamos sob uma inflação de imagens, mas sob uma inflação de imagens saturadas e satura-

1 Amador Fernández-Savater, "Dar a ver, dar que pensar: contra o domínio do automático" in Revista Punkto (https://www.revistapunkto.com/2019/03/dar-ver-dar-que-pensar-contra-o-dominio.html) 
doras: os estereótipos. O estereótipo é um sentido empacotado. Que diz “Aqui não há nada que ver". Ou seja: não há nada que não tenhamos visto já. O mundo está já-visto, já-sentido, já-pensado. O estereótipo é uma resposta automática. O resultado da aplicação de um código sobre a realidade: mediático, político, ideológico, etc. Deste modo, já não vemos ou pensamos, mas simplesmente reconhecemos. Não vemos ou pensamos, mas apenas recordamos o que está no código.”

\section{4.}

E assim, como espectadores, paradoxalmente quantas mais as imagens nos neutralizam o olhar, mais precisamos de imagens: daquelas imagens que nos "toquem", que nos afetem, que nos interroguem: imagens que acentuem um sentido de crise da nossa observação, que coloquem em estado de hesitação a nossa credibilidade: imagens que nos deem a ver.

5.

Fazer imagens versus ver imagens.

Mas ver imagens não é fazer imagens.

Perante o mundo, perante o real, fazer uma imagem, fazer um desenho, é colocarmo-nos perante o problema radical de, do vazio branco do papel, fazer aparecer através de linhas, manchas, marcas que construam uma relação com o que percebemos do que vemos, que construam um sentido para a imagem. Mas é também colocarmo-nos perante o dilema do que vemos (do que queremos ver) em confronto com o universo das imagens que nos habitam e que nos formam. O papel á nossa frente, apesar de vazio, está já carregado de imagens: de memórias, de referências, de pseudo-soluções, de templates prontos a usar. Construir uma imagem, construir um desenho a partir de uma folha em branco, é neste sentido, o arriscar competir com o universo (poluído) das imagens, mas é, antes de isso, ter a consciência que estamos envolvidos como testemunhas activas e envolvidos perante a estranheza do mundo. Perante o real e uma folha em branco, inúmeras perguntas se colocam a quem desenha: o que vejo? como vejo? como agir? como optar? o que desenho? o que excluo do desenho? como superar as armadilhas estabilizadas, normalizadas da "linguagem"? Desenhar é assim continuamente fazer perguntas mais do que afirmar respostas. Assim, desenhar não é transcrever (uma opticidade do visível) mas inscrever a nossa perplexidade, a nossa impotência.

\section{6.}

A paisagem

Perante o espaço, historicamente se construiu a "paisagem" como género, como categoria: impor à amplitude e escala do mundo uma ideia de ordem e de dominação. A paisagem é assim a imagem da natureza dominada como representação. O termo "pitoresco" refere este sentido da transformação do indominável em dominado, do real em imagem.

A prática corrente (senso-comum) do desenho de "paisagem" é a de desenhar (valorizar, acentuar) o "pitoresco" da cena, isto é, o de transformar (a complexidade) do real no apaziguado da imagem (na sua falsa clareza).

7.

O Desenho é um "dispositivo" perigoso: se, por um lado, nos permite e potencia a atenção ao visível do mundo, por outro lado, só nos permite no emaranhado da sua "gramática", da sua linguagem. O desenho 
dá forma mas, ao mesmo tempo, porque se formata, conforma e deforma.

A pedagogia do desenho pode facilmente instituir uma formatação dos códigos e dos procedimentos (templates, esquemas, fórmulas) de adequação do visto, pode formatar os esquemas e os "modelos de representação", impondo um encaixar do visível aos esquemas pré-estabelecidos de resolução: a disciplina do Desenho pode ser a sua morte.

O que Palomino dizia em relação à anatomia ("la anatomía sólo ha de procurar el pintor saberla, para olvidarla”"2), digamo-lo em relação ao desenho.

\section{8.}

Platão dizia "para pensar tem de se arrancar os olhos" mas Albert Camus disse "pensar é aprender de novo a ver e a prestar atenção”.

9.

Perante o lugar: ver e pensar

Para que servem as imagens do desenho (estas imagens)?

Chã das Caldeiras é um lugar único, carregado de extremos contrastes e tensões; é um lugar que escapa ao "pitoresco". Assim obriga a reinventar o olhar, na tensão entre o adquirido e o espanto: obriga a ver e a pensar como se vê.

Chã dá-nos tempo. O seu tempo. O tempo do olhar. Ter tempo: tempo para ver, para sentir, para deambular, para tentar absorver as estranhezas do lugar; restitui-nos o tempo como modo de ver.

10

Este conjunto de imagens que aqui se mostram são, em certo sentido como este texto, fragmentos, detalhes, conexões, observações particulares, peças de um puzzle incompleto e impossível de montar numa unidade totalitária e de suposta coerência, numa imagem ordenada e pacificada. É um atlas de registos e sensações, apontamentos, esquemas e notas, na diversidade dos grandes enquadramentos do espaço às pequenas particularidades dos detalhes, das pessoas, dos animais, das plantas e das relações entre estes elementos.

11.

Queremos ver porque não se entende. Queremos desenhar para ver se entendemos.

Ainda não sei o que Chã das Caldeiras transformou em mim.

Mário Bismarck

2 Antonio Palomino (1653-1726), El Museo pictórico y escala óptica: Libro IV, cap. VI, \$2. 
a






\section{Notas sobre Chã}

Em Chã mora o silêncio de uma paisagem que nos absorve e nos torna seus. Uma paisagem que assombra e envolve.

É impossível descrever a sensação de aterrar na Ilha do Fogo e subir até Chã das Caldeiras pela primeira vez. De repente, encontrava-me em confronto com uma geografia que não tinha nenhum ponto de referência com o que conhecia até então.

O solo é de um negro intenso e profundo absorvendo toda a luz, grandes massas de lava emergem como ondas estagnadas, o horizonte eleva-se. O vulcão e a Bordeira muram Chã e colocam-me em confronto com a minha própria escala e condição. Confesso que não consegui deixar de me sentir tão receoso como estupefacto. A ideia de existir por ali uns tempos não parecia real.

O sentido de comunidade em Chã é a base da sobrevivência neste território. A relação da comunidade com o seu entorno é regulada por princípios de reciprocidade e respeito entre a terra e os seus habitantes (humanos e não humanos).

A terra é mantida comum e os escassos recursos protegidos. Sobreviver em Chã requer este tipo de colaborações entre espécies.

Recordo com carinho as conversas botânicas que tive com Cicilio, percebi então que em Chã a terra torna-se a biblioteca de um povo, a sua farmácia, a sua despensa e a sua identidade.
Durante a caminhada Cicilio falou-me sobre as plantas nativas de Chã, a abordagem a este género de conhecimento era necessariamente diferente. Gera-se um conhecimento intrinsecamente ligado a uma necessidade de sobreviver a partir do entorno e das circunstâncias.

Não será difícil perceber a importância destas plantas para as gentes de Chã. Frequentemente encontrava pequenas construções de pedra volcânica erguidas em volta de videiras para as proteger do ambiente severo. A proximidade formal entre estas estruturas e os Funcos ilustra como a relação entre a comunidade, a terra e tudo o que aí habita está fortemente enraizada neste território.

Cicilio continuou a mostrar-nos os presentes da terra. Entre o magma encontrava Lantisco (Periploca Chevalieri), explicou-nos a importância desta planta; a sua seiva é usada para proteger as mãos de quem constrói e quem cultiva. Vindos do trabalho, colhem uns raminhos desta planta, esmagam-nos para extrair a seiva e aplicam-na nas mãos, de manhã uma camada fina protege as mãos da textura agressiva do solo e da pedra volcânica. Esta planta nativa é ainda usada para alimentação do gado e na cura de pele animal. As plantas em Chã são generosas.

Enquanto percorríamos o sopé do vulcão, parava-se com frequência para tratar de cada planta nativa que se cruzasse no nosso caminho, desviando qualquer pedra que pudesse disturbar o seu crescimento, muitas delas não tinham mais que $15 \mathrm{~cm}$ de altura. 
A maioria destas plantas está em perigo devido às erupções serem cada vez mais frequentes.

Viver numa paisagem implacável como Chã faz as suas gentes engenhosas, conscientes e atentas ao seu entorno, desenvolvendo uma relação contínua e fluída com o conhecimento, este surge, vem de toda a parte e de todas as situações.

Olhar a paisagem de Chã das Caldeiras é perceber as impermanências inerentes ao território. A memória coletiva de um povo traduz-se em paisagem, uma linguagem vivida e plural.

O desenho torna-se o ato mediador entre o meu corpo e o lugar. Procuro uma linguagem visual que condense o que vejo e o que sinto.

Desenhos de pensamento, gestos exploratórios geradores de paisagens de bolso, um desenho táctil que pensa os grafismos e fluidez da linha percorrendo o que se torna horizonte, um plano contínuo e sinuoso. O ato de compor imagens torna-se, aqui, um ato processual de materialização de desejos e princípios.

Dei por mim numa procura dispersa de situações matéricas adaptáveis ao contexto, de súbito os riscadores que trazia já não serviam para desenhar Chã, recombino matérias do desenho e gestos que pretendem pensar a ductilidade rígida da lava e as sonoridades puras e humanas da gente de Chã.

O chão em que caminho lembra-me de onde estou a cada passo. Uma textura cortante e amorfa coloca- -me num permanente processo de consciencialização do que é viver em Chã.

Desenho para perceber; o gesto mínimo do desenho torna-se potenciador de perceções de geografias e das suas ficções poéticas.

A monumentalidade da paisagem coloca-me no plano contemplativo, a mão procura seguir o olhar num gesto intuitivo e numa tentativa de entendimento do meu entorno, uma rememoração de imagens latentes que foram demasiado fugazes para conseguir captar com a lente. Escrevo, anoto, nomeio, o registo gráfico não é senão uma consequência da linguagem, fala-se com os desenhos, comunica-se e interage-se.

Desenhava a roupa a secar em cima do magma num dia quente, pouco depois larguei o meu desenho para desenhar com eles, as crianças curiosas que rapidamente esboçavam aquilo que eu andava à procura: um imaginário que era o deles, o de Chã.

É curioso pensar como as formas de representação estão profundamente relacionadas com o sítio e o contexto geográfico onde crescemos. Não demorou muito até aparecer o primeiro vulcão, um funco ou até a Bordeira. Desenhar é também uma forma de pertença, de reativação das origens e das referências de cada um

O desenho do pequeno Zemer é uma representação atenta e intuitiva do que é uma casa em Chã, uma casa em constante mudança, uma estrutura crescente que se adapta às necessidades momentâneas. As casas são melhoradas e ampliadas como se pode 
e se precisa. Observei Zemer a desenhar um lar, à pequena casinha acrescenta uma divisão, e outra, deste aglomerado sai um pequeno caminho que liga a outro território. No fim este desenho traz consigo muito do que é Chã - um território em contínua mudança e sobretudo destaca a gigantesca resiliência das suas gentes.

O movimento constante de alteração da paisagem pela própria natureza introduzincerteza no quotidiano de Chã. No entanto, (re)estabelece-se o habitat mais uma vez. Constrói-se a partir de ruínas, em cima dos restos das suas casas antigas, escavando o magma; usando ferramentas, estruturas e métodos simples para se adaptar à nova paisagem. A inevitabilidade da mudança é absorvida e exige conhecimento intuitivo de sobrevivência.

A conexão mística dos habitantes de Chã com o território é muito mais do que eu alguma vez conseguirei perceber.

Cicilio disse-me que passou os meses da erupção de 2014 na Bordeira a ver o magma a varrer a aldeia da superfície, a pedra líquida engoliu a maior parte das casas de Chã. Não consigo imaginar como será ver o próprio lar ser destruído e ser incapaz de mudar isso. Descreveu o calor, o lento e implacável caminho que o magma percorreu, bloqueando a única estrada de acesso. Não importa com quem falasse, nunca encontrei qualquer tipo de revolta ou ressentimento contra o vulcão ou contra a natureza. Como será possível?

É incrível como a relação simbiótica e de respeito com a terra consegue ser tão genuína e honesta. "O nosso coração mora aqui!" dizem eles.

Fico sempre estupefacto com a avassaladora capacidade de um lugar conseguir ativar o sentido de pertença de quem lá vive. A inevitabilidade da mudança é abraçada.

O vulcão torna-se um agente geológico vivo, um gigante adormecido com quem se coexiste e a quem se tem o maior e mais genuíno respeito.

Há lugares que também são nossos sem o sabermos, a noção de origem ramifica-se e acumula-se pelo movimento.

No fundo ressoa o som da Talaia Baxu e os sorrisos mais genuínos fazem-me perceber que trago de Chã muito mais do que alguma vez poderei devolver.

\section{"Nada em mim é rígido ou intransigente. Articulo- - me com a mutabilidade da atmosfera, a qualidade da paisagem."}

1 HELDER, Herberto; Photomaton \& Vox; Porto Editora; 2015, 6a edição; p. 108 



\section{Chegada}

Não era a minha primeira vez em Chã das Caldeiras, mas seria a minha primeira vez depois da erupção que começou a Novembro de 2014 e que chegou ao fim no dia 8 de Fevereiro de 2015. As expectativas eram grandes. Tentar reconhecer os sítios onde estive, tentar perceber o que tinha sido ou não destruído, tentar perceber o que já estava recuperado. Não foi fácil reconhecer o antes, pois o vulcão tinha engolido tudo e com ele as minhas memórias do espaço. O que permanecia na minha memória não encaixava nesta nova paisagem. Era um novo território.

A sensação de que um abraço lento de lava tinha recolhido a si todo um presente, devolvendo ao povo a possibilidade sádica de começar tudo de novo. Esta sensação de renovação, provocou uma ambivalência de pensamentos que despertaram uma certa cobiça por este povo. Como é possível viver com tão pouco, sabendo que o pouco mais cedo ou mais tarde será

\section{Permanência}

Fui para o Fogo com um propósito. Com a missão de ver para além do olhar. De pensar com o ver, pensar sobre o que vejo e desenhar o que percepciono. A percepção é uma construção em devir. E a representação, se, por um lado, é a transformação do que se percepciona num outro espaço, é também ela uma construção. Ver através do desenho e com o desenho não é igual a ver com o olhar ou através da lente. Ver com o desenho implica diferentes momentos de ver. levado pelo Vulcão, o Pai, como é apelidado pelos habitantes de Chã das Caldeiras. Como mesmo assim se consegue ser tão resiliente e generoso?

A natureza leva-os a uma renovação forçada. Um começar do zero permanente. O poder fazer parte desta gente, mesmo que por tão pouco tempo que fosse, proporcionou-me uma experiência de alteridade que doutra forma não me seria possível. Um exercício que só consigo fazer no confronto com esta diferença. Um exercício, egoísta, que tenta a partir da experiência dos outros retirar algo para si. Este deslocamento, a contemplação da Paisagem, do Silencio, da Bordeira, do Vulcão, das Pessoas permitiu-me recentrar e encontrar um tempo e um espaço, que me permitiu pensar que ainda existem coisas para fazer, sítios e pessoas onde poderei ajudar a produzir a diferença, sítios que me provocam e que me obrigam a pensar.

Primeiramente vemos para conhecer, um olhar que atenta desmontar o que nos rodeia, que faz o exercício de entender e descodificar o real. Posteriormente, um olhar ativo, que existe em paralelo no tempo. Um olhar que ao mesmo tempo que conhece dá a conhecer. Nesta tradução, entre o que se vê e o que se representa, vemos coisas diferentes, estamos atentos de uma outra forma. Uma atenção ativa onde vários 
factores interagem em simultâneo. Se, por um lado, temos a realidade, por outro temos a representação dessa mesma percepção que nem sempre ou maior parte das vezes não são coincidentes. O privilégio de aprender, de ver de novo, de voltar a ver com tempo, um tempo do desenho, possibilita recriar o olhar da-

\section{Ecos}

Este incentivo, que vem da força da paisagem, cria gestos e imagens que já não são do universo do ver mas do recriar a realidade. Já não estou no ambiente de Chã das Caldeiras, já não tenho o tempo parado e lento que tinha na semana em que apenas me limitei a ficar a ver e a desenhar. A condição é outra. É a condição de renomear, de dar uma outra forma e uma outra visibilidade da realidade. $\mathrm{O}$ impacto que provocou no meu trabalho é bem visível. Espelha a necessidade de partilhar com os outros, e, de reconsiderar, para nós próprios, aquilo que se viveu. Se no local registei pormenores, conversas, apontamentos, vistas gerais da paisagem, cores, texturas de chã das caldeiras, no revisitar de todo este levantamento, o trabalho é outro. Já não se trata de ver e conhecer mas sim de interpretar, de reconhecer nos materiais, nos gestos, nos grafismos uma outra dimensão da representação. O negro da paisagem, a energia do solo já não é coisa material, é linguagem, é algo faz parte da intenção de representar o impacto desta experiência em mim e no meu trabalho. É o que ainda está por trazer, por devolver às imagens. Um processo na procura de encontrar a mesma energia e o mesmo impacto que Chã das Caldeiras e as sua gentes teve em mim. É um campo aberto de incertezas de gestos que me levam a desenhar. quilo que vejo e do que desenho. Esta disponibilidade e atenção que dedico enquanto desenho é apenas um inicio, um principio de qualquer coisa que se entranha. O negro da paisagem, a força e organicidade do magma libertam uma energia que criaram ressonâncias bem visíveis no meu trabalho.

O referente, o mote, já não é mais o lugar, mas antes a experiência de representar esse lugar. O desenho é agora a origem e a fonte de ativações que me levam a continuar a desenhar. É a partir deste Desenho que penso Chã das Caldeiras, que partilho o que me aconteceu, que descubro e compreendo.

Contrariamente ao povo de Chã, penso no vulcão como sendo uma mulher. Uma mãe, que nos obriga a refazer tudo de novo, sobre o olhar do pai atento, a Bordeira, que limita de forma passiva o campo de ação da lava. Para mim, o vulcão, é fêmea. Pode parecer despropositada a observação, mas a construção dos meus desenhos dos vulcões a isso me levou. Começo a perceber que alguns já não são vulcões mas sim vaginas, que, da mesma forma que o Vulcão expelem o calor que sai dentro dum corpo.

Até quando não sei, mas os ecos continuam a ressoar criando vibrações e oscilações que conduzo para os meus desenhos.

Sílvia Simões 



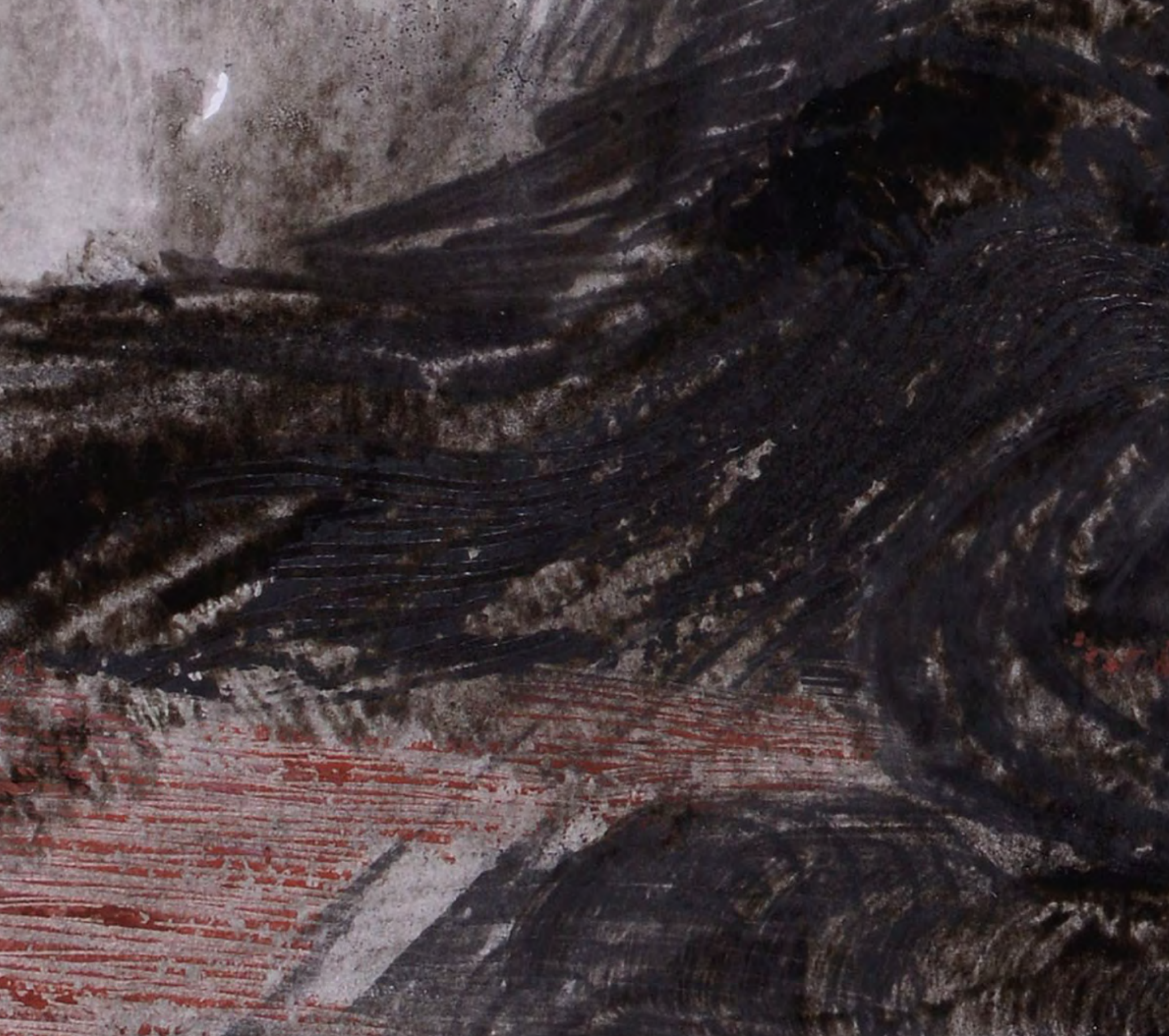

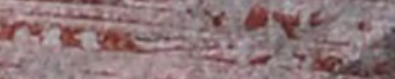

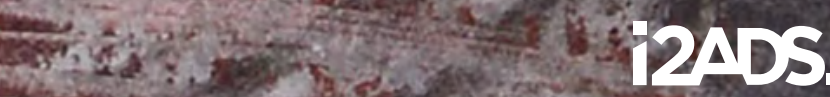

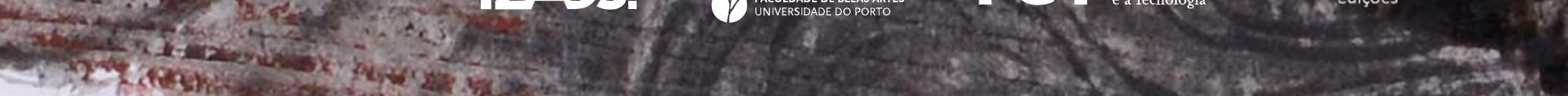

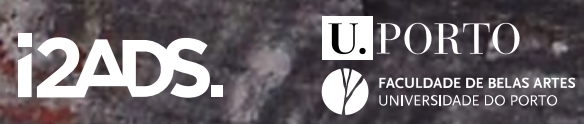
FCT $=$ ponto \& vírgula 2. Xx: ediçoes art 